\title{
Regulation of the G1/S Transition in Hepatocytes: Involvement of the Cyclin-Dependent Kinase Cdk1 in the DNA Replication
}

\author{
Anne Corlu and Pascal Loyer \\ Inserm UMR S 991, Foie Métabolismes et Cancer, Université de Rennes 1, Hôpital Pontchaillou, 35033 Rennes Cedex, France \\ Correspondence should be addressed to Pascal Loyer, pascal.loyer@univ-rennes1.fr
}

Received 29 June 2012; Accepted 29 August 2012

Academic Editor: Chantal Desdouets

Copyright (๑) 2012 A. Corlu and P. Loyer. This is an open access article distributed under the Creative Commons Attribution License, which permits unrestricted use, distribution, and reproduction in any medium, provided the original work is properly cited.

\begin{abstract}
A singular feature of adult differentiated hepatocytes is their capacity to proliferate allowing liver regeneration. This review emphasizes the literature published over the last 20 years that established the most important pathways regulating the hepatocyte cell cycle. Our article also aimed at illustrating that many discoveries in this field benefited from the combined use of in vivo models of liver regeneration and in vitro models of primary cultures of human and rodent hepatocytes. Using these models, our laboratory has contributed to decipher the different steps of the progression into the G1 phase and the commitment to S phase of proliferating hepatocytes. We identified the mitogen dependent restriction point located at the two-thirds of the G1 phase and the concomitant expression and activation of both Cdk1 and Cdk2 at the G1/S transition. Furthermore, we demonstrated that these two Cdks contribute to the DNA replication. Finally, we provided strong evidences that Cdk1 expression and activation is correlated to extracellular matrix degradation upon stimulation by the pro-inflammatory cytokine TNF $\alpha$ leading to the identification of a new signaling pathway regulating Cdk1 expression at the G1/S transition. It also further confirms the well-orchestrated regulation of liver regeneration via multiple extracellular signals and pathways.
\end{abstract}

\section{Introduction}

The cell cycle is highly conserved cellular process allowing a cell to divide in two identical daughter cells. Although mammalian cells show a higher degree of complexity, the molecular pathways controlling the progression throughout the cell cycle and both DNA replication and mitosis are relatively well conserved among eukaryotic cells [1]. The most conserved pathways of the cell cycle are probably DNA replication and major check-points for DNA integrity and mitosis. In contrast, more specific pathways control the transition from quiescence to DNA replication in eukaryotic organisms. In mammalian cells, specific combinations of extracellular signal stimuli induce the exit from quiescence, progression throughout G1 phase, and commitment to DNA replication. Proliferation stimuli include a vast superfamily of growth factors and cytokines activating downstream intracellular signaling pathways mainly through a cascade of phosphorylation and dephosphorylation events that ultimately triggers changes in gene expression in order to induce the proteins required for duplication of cellular components including DNA and the subsequent mitosis [2]. Among these protein kinases, the sequential activation of the cyclindependent kinases (Cdks) has been extensively characterized and plays a crucial role in regulating the entry into and progression through the cell cycle [3].

The discovery of the first Cdk, Cdk1 initially named cdc2 in yeast, has opened a large field of research leading to the identification of many cell cycle regulators and the pathways they are involved into. The first studies regarding the cell cycle regulation were conducted using cell models such as yeasts and oocytes from amphibians and marine organisms that synchronously progress throughout the different phases of the cell cycle in order to analyze expression and activation of regulators at each step of the cell cycle. From the mid1970 s to the late 1980s, the burst of data obtained in these eukaryotic cells leads to the identification of major cell cycle regulators including the cyclins [4] and their catalytic subunit partners the Cdks [3]. Mammalian homologs of these cell cycle regulators were subsequently isolated and by 


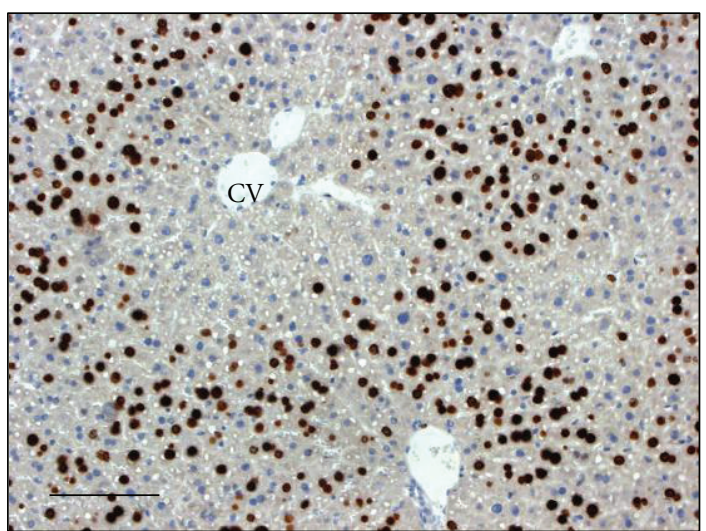

(a)

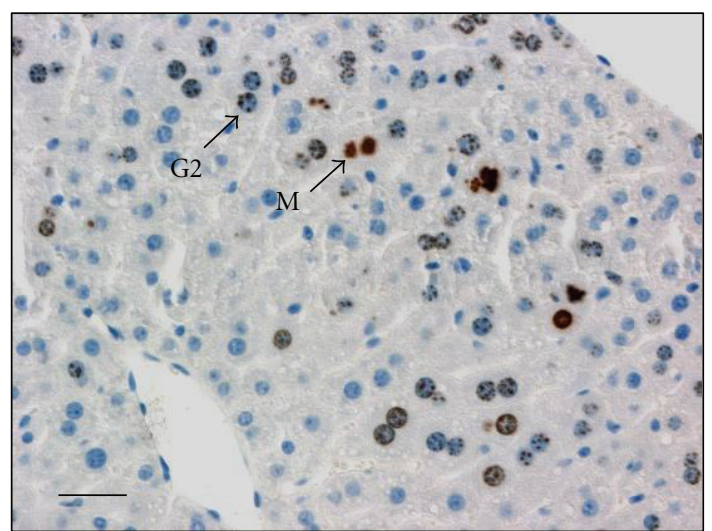

(b)

FIGURE 1: Sections of mouse liver evidencing detection of DNA replication and G2 phase. Mice were hepatectomized, injected at 46 hours after hepatectomy with BrdU, and killed 2 hours later (at $48 \mathrm{~h}$ ). Livers were fixed for histological studies and detection of BrdU to visualize hepatocytes replicating DNA (a) or phosphohistone H3 (b) to detect cells in G2 phase. (a) This low magnification picture shows the detection of BrdU positive cells replicating DNA, illustrating that replicating hepatocytes are initially localized in the vicinity of the portal vein while around centrolobular veins (CV) only few hepatocytes replicate DNA at $48 \mathrm{~h}$. (b) A higher magnification picture shows nuclei of hepatocytes reaching G2 phase (detection of phosphohistone H3 positive cells with punctuated nuclear signal: G2 and mitosis (M). Bars: $100 \mu \mathrm{m}$.

the mid-1990s a network of Cdk/cyclin complexes emerged opening a complete new field in cancer research since many of these cell cycle regulators are altered during oncogenesis and/or are potential therapeutic targets for cancer treatments $[5]$.

In vivo, cell renewal is mainly achieved through the proliferation of adult stem and progenitor cells that proliferate actively although these cells can probably arrest in G0 before additional rounds of division or entering a program of differentiation. Because progenitor cells are rare cells and cannot be easily purified, there are few data regarding cell cycle regulation in these cell types. There are, however, adult differentiated cell types that remain arrested in G0, which can reenter the cell cycle for several rounds of division upon appropriate proliferation stimuli including lymphocytes [6] and fibroblasts [2] which can be isolated relatively easily from blood or skin, respectively, plated in culture and used for cell cycle studies. Although these cell types are suitable models for conducting cell cycle studies, there have been a limited number of publications reporting cell cycle data using lymphocytes and mainly because these primary cells need to be renewed for each experiment. The most widely used cell models in the field of cell cycle regulation are the immortalized or transformed cell lines artificially synchronized by drug treatments arresting the cells in G1/S or $\mathrm{G} 2 / \mathrm{M}$ transitions and the primary fibroblasts arrested by serum starvation in a G0-like state. Although the scoop of this paper is to focus on the progression in late $\mathrm{Gl}$ and the G1/S transition, it is important to point out that the comparison between these in vitro models of G0-like or early G1 arrest and in vivo G0 arrested cells was poorly documented for many years. However, recent reports evinced differences between "arrested" cells in various conditions $[7,8]$. For instance, the serum starvation of fibroblasts plated at low density obviously provides an experimental condition completely different from G0-arrested cells in vivo, which stop dividing for other reasons than the lack of growth factors or nutrients. Nevertheless, these in vitro synchronized mammalian cells provided powerful models to investigate cell cycle in mammalian cells and allowed to collect crucial data on the progression from early G1 to the commitment to DNA synthesis.

In mammals, synchronized cell proliferation in vivo is restricted to very few cell types among which proliferation of hepatocytes during liver regeneration following partial hepatectomy has probably been the most used model. In this paper, we will focus on the peculiar regulation of the Cdk1 expression and activation during the hepatocyte cell cycle.

\section{In Vivo and In Vitro Models of Synchronized Hepatocyte Proliferation}

In contrast to other regenerating tissue, the liver regeneration process involves massive proliferation of differentiated hepatocytes in the remnant tissue (Figure 1). The liver regeneration is triggered experimentally by liver resection or by injection of hepatotoxic agent leading to cell death either by necrosis or apoptosis such as the thioacetamide [9] or CCl4 [10]. However, the most commonly used model of liver regeneration is the partial hepatectomy in rat or mouse. After $2 / 3$ hepatectomy, liver regeneration begins with a first synchronous wave of hepatocyte proliferation, followed by sequential proliferation of biliary, kupffer, and endothelial cells $[11,12]$. Proliferation of mature hepatocyte first occurs within the parenchyma in the vicinity of the portal triads and proceeds to the pericentral area close to the centolobular veins [13] (Figure 1). The unique ability of differentiated hepatic cells to exit from quiescence and reenter the cell cycle after a tissue loss has aroused numerous studies to identify exogenous factors triggering the liver regeneration and regulators of hepatocyte cell cycle progression. Both in vivo and in vitro models have been extensively studied for 
identifications of the extracellular stimuli regulating cell cycle of mature hepatocytes and downstream signaling pathways.

Using in vivo models, Molten and Bucher have shown that circulating growth factors present in the serum of hepatectomized rats induce hepatocyte replication in parabiosed nonhepatectomized animals [14]. Using primary culture of rat hepatocytes, HGF, TGF $\alpha$, EGF, heparin-binding EGFlike growth factor (HB-EGF), and amphiregulin have been identified as potent hepatocyte growth factors [12]. However, the injection in rat of these growth factors does not induce massive hepatocyte DNA replication since normal hepatocytes in vivo are not able to respond to mitogenic signal without priming events allowing hepatocytes to become "sensitive" to growth factors. The proinflammatory cytokines TNF $\alpha$ and IL- 6 are the early stimulus during the liver regeneration allowing the exit of hepatocytes from quiescence and the priming of hepatocytes $[15,16]$. Rapid induction of urokinase activity and urokinase receptor expression appeared within 5 min followed within $30 \mathrm{~min}$ by a rapid activation of NFkB and STAT3. These transcription factors participate to the induction of a subset of genes called "immediate early genes" including c-fos and c-Jun leading to an increase in AP1 activity.

Then high levels of HGF are found in plasma around two hours after PH. This initiation phase controlled by proinflammatory cytokines thus results in the G0/G1 transition and early G1 progression allowing hepatocytes to become sensitive to growth factors and competent for commitment to DNA replication. Therefore, the complex regenerating process is now divided in three distinct phases: the initiation, proliferation, and termination steps. In rat and, to a lesser extent, in mouse the first wave of hepatocyte proliferation following partial hepatectomy $(\mathrm{PH})$ is synchronous. In both rat and mouse, within less than 15 minutes after the $\mathrm{PH}$, hepatocytes exit quiescence and enter in G1-phase [17]. The timing of DNA replication and mitosis is however different between the two species. The peak of DNA synthesis is observed at $22-24 \mathrm{~h}$ in rat followed by a peak of mitosis at 28-30 h [18-22] while DNA replication occurs nearly $24 \mathrm{~h}$ later in mice. Seven days later, the liver has recovered nearly $70 \%$ of its initial mass.

Isolation of hepatocytes from rodent and human liver and establishment of in vitro culture systems have provided powerful experimental in vitro models to identify extracellular signals and to study intracellular signaling pathways regulating differentiation and controlling the ratio between proliferation and apoptosis in liver. Enzymatic liver dissociation triggers G0/G1 transition of quiescent hepatocytes, which progress up to and arrest in mid-G1 phase in absence of growth factors in primary culture $[23,24]$. It has been proposed that rupture of cell-cell interactions [23] and induction of oxidative stress [25] or proinflammatory response [26] during liver dissociation could be responsible of hepatocytes reentry into the cell cycle, mimicking the effect of proinflammatory cytokines TNF $\alpha$ and IL6 which control the G0/G1 transition in vivo during liver regeneration $[11,27]$. In agreement, we demonstrated that TNF $\alpha$ was released into the perfusion buffers during the in situ procedure of hepatocyte isolation by collagenase dissociation of the rat and mouse liver with various amounts ranging from 100 to $500 \mathrm{pg} / \mathrm{mL}$ (Corlu A and Loyer P, unpublished data).

In pure culture of hepatocytes, expression of liver specific functions progressively decreases and apoptosis eventually occurs within a week through the activation of caspases 3,8 , and 9 in hepatocytes [28-30]. Nevertheless, this in vitro culture model has been very useful to identify survival factors and mitogens based on their ability to induce DNA replication. In pure culture of rat hepatocytes, addition of $25 \mathrm{ng} / \mathrm{mL}$ of EGF in the culture induces a robust and partially synchronized DNA replication followed by the mitosis (Figure 2). Using this synchronous primary model, our laboratory and others investigated cell cycle regulation $\mathrm{Cdk} /$ cyclin expressions and activations [12, 31-33].

More recently, we used a coculture model associating rat hepatocytes with rat liver epithelial cells (RLEC also called BEC for biliary epithelial cells), in which heterotypic cellcell contacts are restored and a spontaneous early production and deposition of extracellular matrix are observed [3436]. This coculture model (Figure 3 ) compared to the pure culture of hepatocytes exhibits numerous advantages: adult hepatocytes remain highly differentiated for several weeks [37] and are unable to proliferate under EGF or HGF stimulation alone as in liver tissue [38]. Therefore, based on the data obtained in vivo, we successfully designed a stimulation procedure allowing multiple hepatocyte division cycles without loss of differentiation [39]. In this coculture system, differentiated and quiescent hepatocytes are able to proliferate under costimulation with TNF $\alpha$ and EGF or HGF.

This co-stimulation with TNF $\alpha$ and EGF leads to proliferation of nearly all the hepatocytes over a week [39]. Three days after TNF $\alpha / \mathrm{EGF}$ or TNF $\alpha / \mathrm{HGF}$ stimulation, at least $35 \%$ of hepatocytes divide whereas no DNA synthesis is observed in presence of HGF or EGF alone. Both mono- and binuclear hepatocytes progressed up to mitosis and cytokinesis allowing the significant expansion of hepatocyte colonies. These results are in agreement with in vivo experiments, in which coinjection of TNF $\alpha$ and growth factors induced hepatocyte proliferation in absence of partial hepatectomy [15]. Moreover, $\mathrm{TNF} \alpha$ alone did not induce hepatocyte proliferation in coculture as observed in vivo [15] and in long-term DMSO cultures [40]. Remarkably, hepatocytes gradually stop synthesizing DNA even under prolonged TNF $\alpha /$ EGF stimulation. We demonstrated that a cell cycle arrest following the first wave of divisions is essential for inducing a second round of proliferation. Although cells do not proliferate in a synchronous manner in this coculture model, this in vitro cell system mimics the behavior of the hepatocytes in the whole liver and was used to investigate the involvement of cell-cell and cell-matrix interactions in the regulation of the hepatocyte cell cycle.

\section{The G1 Phase and the Mitogen-Dependent Cell Cycle Progression}

Nearly three decades ago, the in vitro synchronized fibroblasts allowed to distinguish different steps in the G1 phase 


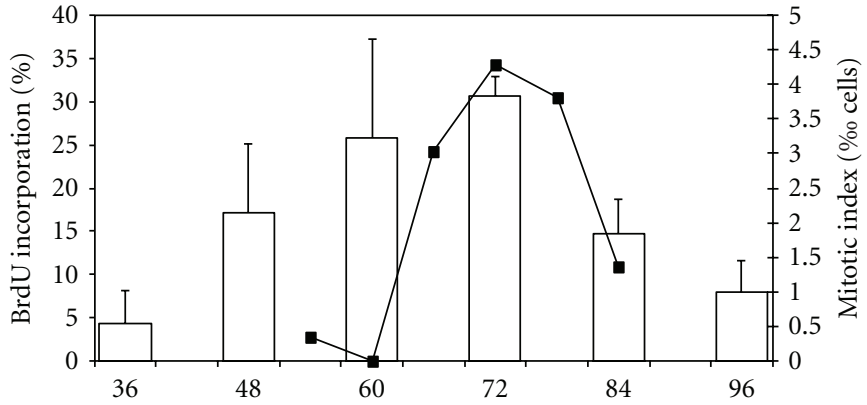

(h)

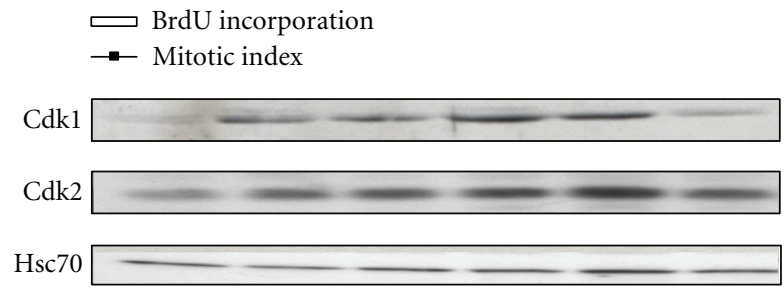

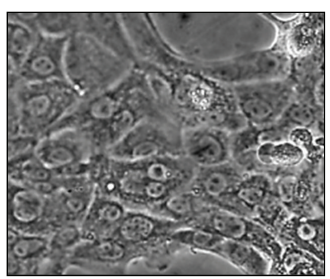

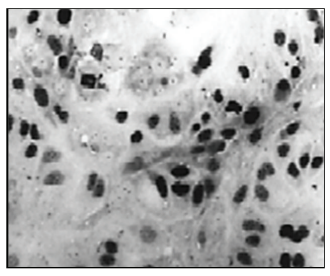

FIGURe 2: Proliferation of rat hepatocytes in pure culture. Isolated rat hepatocytes (right, picture in phase contrast) seeded at low density $\left(<5.10^{4}\right.$ cells $\left./ \mathrm{cm}^{2}\right)$ and stimulated with EGF $(25 \mathrm{ng} / \mathrm{mL})$ commit to DNA synthesis (BrdU incorporation, histogram and in situ immunodetection of BrdU positive cells) and complete the cell cycle (mitotic index, right axis). Western blotting of Cdk1 and Cdk2 and the loading control Hsc70.

progression and to define the concept of "restriction point" [41]. The progression through the G1 phase can be divided in several periods, which are different between cell types. For instance, the progression of fibroblasts throughout G1 could be divided in 4 periods: competence, entry, progression, and assembly (Figure 4). The stimulation of starved fibroblasts by PDGF promotes progression in early G1 until the restriction point $\mathrm{C}$, defining the so-called competence, but fails to allow progression in mid- and late G1 [42-45]. Then the progression in late $\mathrm{G} 1$ and $\mathrm{S}$ phase can be achieved by subsequent stimulation with EGF or insulin [46, 47]. However, in absence of essential amino acids, cells arrest in mid-G1 at a restriction point named "V." The progression between points " $\mathrm{C}$ " and "V "defines the period called entry [48] while the progression between point " $\mathrm{V}$ " and the mitogen-dependent restriction point (point " $R$ ") is called progression. Finally, the period beyond the mitogen-dependent restriction point and before the burst of DNA synthesis is named assembly [49]. A minimal period of stimulation is required to reach the late G1 and, beyond this point, the cell cycle is completed even after removing growth factors. This restriction point is very similar to the start point in yeast that controls the commitment to $S$ phase [50]. It is essential to distinguish the G1 progression between cells that proliferate actively and enter G1 after completion of mitosis and cells reentering the cell cycle after a prolonged quiescence or G0. The transition from G0 to G1 is characterized by a profound modification of the expressed gene profile [2] required for metabolic adaptation to cell proliferation and resulting in a longer period of time for the cells to initiate progression in late G1 compared to the cells exiting mitosis.

Primary cultures of rat and mouse hepatocytes were widely used to analyze hepatocyte cell cycle entry and progression through the G1 phase. Our group has shown that during cell isolation rat hepatocytes expressed immediate early protooncogenes such as c-fos and c-myc suggesting a "spontaneous" G0/G1 transition following cell-cell interaction destruction [23]. On the other hand, it had been also demonstrated that rat hepatocytes in pure culture undergo DNA replication when they were stimulated by growth factors alone $[51,52]$. Thus, we hypothesized that hepatocytes were arrested in G1 phase in absence of growth factors and that by comparing unstimulated and stimulated hepatocyte it should be possible to characterize the different steps of G1 phase in hepatocytes [24]. Confirmation that collagenase perfusion of the liver induces the G0/G1 transition of quiescent normal rat hepatocytes was provided and we showed that progression in late G1 triggers hepatocyte ability to respond to growth factor alone. Importantly, demonstration that hepatocytes are able to progress from an early G1 to a mitogen-dependent restriction point ( $R$ point) located to mid-late G1 was shown (Figure 5). Indeed, in absence of growth factor and serum, hepatocytes are able to progress up to mid-late G1 phase as shown by the sequential overexpression of c-fos, c-jun, c-myc, jun D and then c-Ki-ras and p53. In addition, low levels of cyclin D1 and D2 are observed while cyclin A and Cdk1 are not expressed. Moreover, the progression towards the G1/S is strictly dependent upon the stimulation by growth factor. To further demonstrate the mitogen-dependent restriction point, we hypothesized that if the addition of EGF was performed at any time point before cells had reached the $\mathrm{R}$ point, the onset of DNA synthesis would not be affected. In contrast, if the addition of EGF occurred after cells had reached the R point, a delay in the onset of DNA synthesis should be observed. The hypothesis was experimentally confirmed: when addition of EGF occurred at different times but prior to $42 \mathrm{~h}$ after hepatocyte seeding, DNA replication 

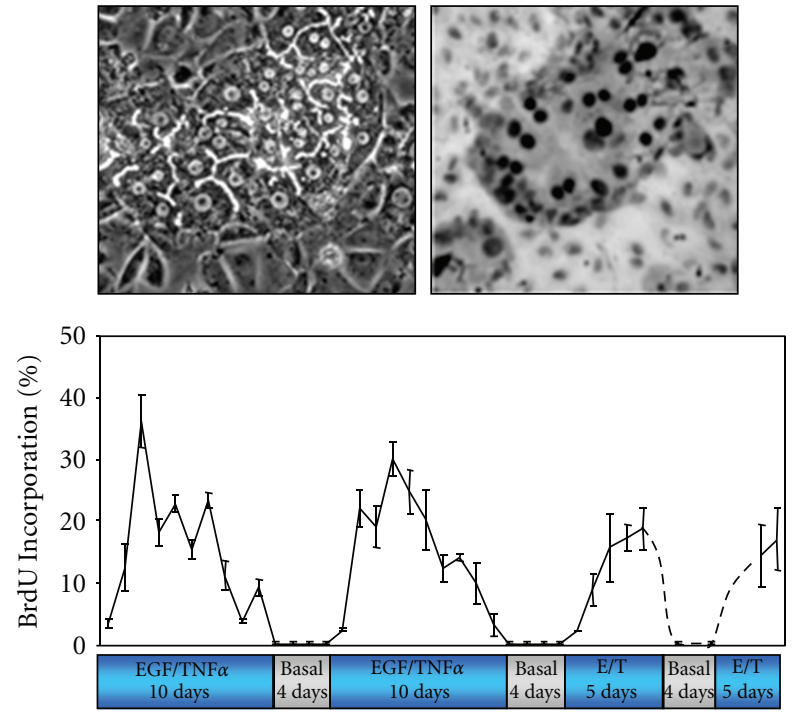

FIgURe 3: Proliferation of rat hepatocytes in coculture. Upper left: phase contrast picture of a colony of rat hepatocytes surrounded by Rat Liver Epithelia Cells (RLECs). Upper right: indirect immunodetection of BrdU positive hepatocytes evidencing DNA replication within the hepatocyte colony. Chart: multiple waves of replication in hepatocytes maintained in coculture over 52 days. Four periods of stimulation using EGF and $\mathrm{TNF} \alpha(\mathrm{E} / \mathrm{T})$ were separated by culturing the cells in basal medium lacking the mitogenic cocktail. The BrdU was incorporated for $24 \mathrm{~h}$ and at each time point triplicate cultures were fixed and stained for BrdU detection.

took place at the same time $(48-60 \mathrm{~h})$ while for delayed stimulations the onset of DNA synthesis was postponed (Figure 5). A lag phase between the $\mathrm{R}$ point and the onset of the DNA synthesis appeared to be approximately $12-18 \mathrm{~h}$.

In this hepatocyte primary culture, Cdk2 mRNA is detectable throughout the G1 phase but significantly increased after the EGF stimulation. Cyclin A is detected at the entry of S phase and Cdk1 - and Cdk2- dependent histone $\mathrm{H} 1$ kinase activity is mainly detected in S and M phases. Weak levels of cyclin E mRNA are found in unstimulated cultures, but levels of this mRNA greatly increased after growth factor stimulation. Surprisingly, cyclin D3 mRNAs appear to accumulate in absence of EGF stimulation whereas a drastic increase in cyclin D1 expression accompanies the $\mathrm{R}$ point overcrossing. The cyclin D1 mRNA accumulation correlates with the R point onset and the cyclin D1 protein is detected 10-15 h later. In accordance with these observations, accumulation of cyclin D1 is also detected when the hepatocytes are stimulated by HGF [53]. Importantly, if progression beyond the restriction is delayed by late EGF stimulation, cyclin D1 induction is postponed accordingly demonstrating that cyclin D1 induction is essential for cell cycle progression at the mitogen-dependent restriction point.

The question arises whether this restriction point existed in vivo. Nicely, a growth factor dependency in mid-late G1 phase of proliferating rat hepatocytes in vivo was also observed [54]. To reach that conclusion, we first analyzed the expression of cyclin D1 during liver regeneration and showed its induction at $12 \mathrm{~h}$ after hepatectomy, which is a time coinciding with the $2 / 3$ of G1 progression as previously shown in primary culture of rat hepatocytes. We next isolated rat hepatocytes isolated $5,7,9,12$, or $15 \mathrm{~h}$ after $\mathrm{PH}$ and showed that only those isolated from $12-15 \mathrm{~h}$ regenerating livers were able to replicate DNA without growth factor stimulation. Moreover, intravenous administration of a MEK inhibitor (PD98059) in vivo, before MEK activation at $10.5 \mathrm{~h}$ post-PH, was able to inhibit cyclin D1 mRNA accumulation and hepatocyte DNA replication demonstrating that MEK/ERK signaling pathway was involved in cyclin D1 induction and $\mathrm{R}$ point overcrossing. To the best of our knowledge, these data provide the unique evidence that the mitogen-dependent restriction point identified in cultured hepatocytes exists in vivo in whole organs and animals. These results were strengthened by Albrecht's observations showing that transient enforced expression of cyclin D1 in hepatocytes stimulates assembly of active cyclin D1/cdk4 complexes, robust hepatocyte proliferation, and liver growth in rat liver [55]. However, in this in vivo model, after several days, hepatocyte proliferation is inhibited despite the persistence of high levels of cyclin D1 and cyclin E, suggesting that antiproliferative response related to marked upregulation of $\mathrm{p} 21^{\mathrm{Cip} 1}$ represses cyclin D1/cdk4- and cyclin E/cdk2-dependent kinase activities. More recently, using mice carrying a floxed EGFR allele to inactive the EGF receptor, Natarajan et al. [56] observed delayed liver regeneration characterized by defective G1/S phase entry, reduced cyclin D1 expression followed by moderate Cdk2 and Cdk1 expression. In parallel, these authors reported an increased mortality after PH associated to high levels of TNF $\alpha$ in the serum. They also suggested that soluble $\operatorname{TNF} \alpha$, which is a priming agent for hepatocytes, was produced at high levels by liver cells to compensate cell cycle arrest with a subsequent induction of cell death in absence of proliferation.

Similar studies were performed in many other cell models leading to the conclusion that in all cell types the G1 phase could be divided in subphases corresponding to major steps in the metabolic adaptation required for cells to replicate DNA and divide. However, for each cell types, specific growth factors and signaling pathways are involved. Among the soluble factors inducing proliferation, the "priming" factors promote in early G1 while combination of cytokines and growth factors stimulates progression in late G1 and the G1/S transition. Then, following binding to their receptors, priming and growth factors activate multiple phosphorylation events involving multiple protein kinases especially the MAPKinase pathways [57, 58]. Moreover, multiple crosstalks between these pathways exist and lead ultimately to the activation of transcription factors that sequentially trigger induction of cell cycle regulators such as the cyclins and Cdks.

\section{The Cell Cycle Is Regulated through the Sequential Activation of Cdk/Cyclin Complexes}

Progression of eukaryotic cells through the cell cycle is regulated by the sequential formation, activation, and subsequent inactivation of structurally related serine/threonine 


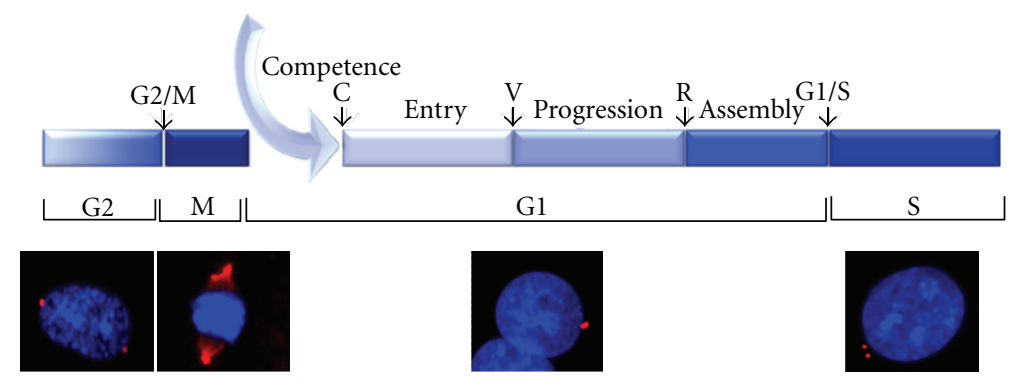

FIgure 4: Progression through the G1 phase is divided into several subphases. Photographs illustrate detection of cells in G2, M, G1, and S phases: the cells were stained with DAPI (DNA) and indirect immunofluorescence detection of $\gamma$-tubulin in centrioles was used to discriminate between cells in G1 phase (a single centrosome), S phase (two centrosomes side by side), G2 (two centrioles on each side of the nucleus), and $\mathrm{M}$ (centrioles pulling apart the chromosomes). Four steps were identified during the G1 phase of the cell cycle: competence, entry, progression, and assembly.

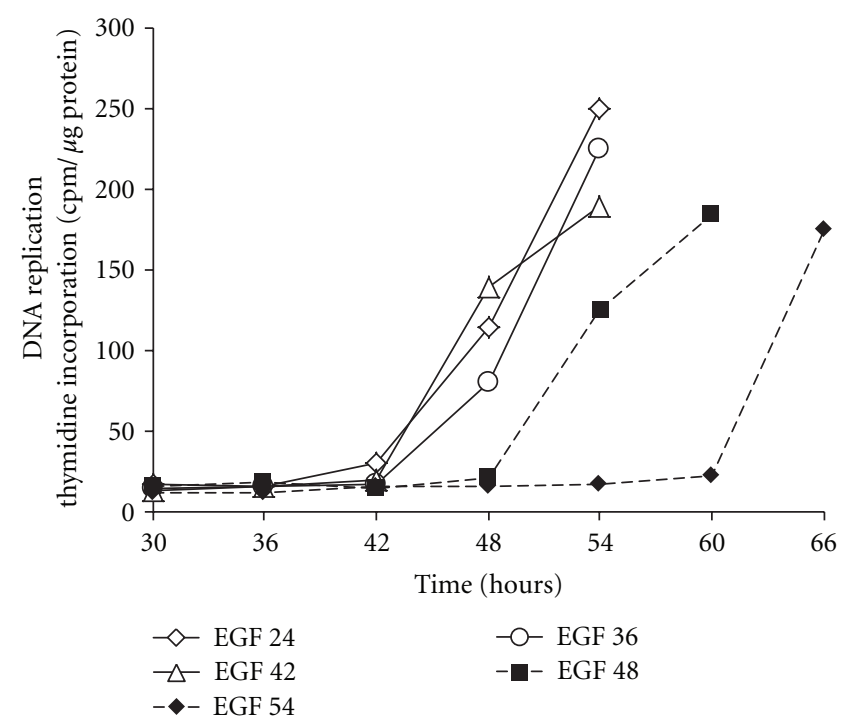

FIGURE 5: Evidencing the $\mathrm{R}$ point in primary rat hepatocytes. In absence of EGF rat hepatocytes do not replicate DNA. However, they sequentially express early G1 phase markers strongly suggesting a cell cycle arrest in midlate G1 phase. The mitogen-dependent restriction point was localized by performing stimulation with EGF at different time points $(24,36,42,48,54 \mathrm{~h})$ after seeding the hepatocytes. Then the DNA replication was monitored by measuring the incorporation of radiolabelled thymidine into the hepatocyte DNA. For stimulations between 24 and 42 h, DNA replication began between 48 and $54 \mathrm{~h}$. When cells were stimulated at 48 or $54 \mathrm{~h}$, DNA replication was significantly delayed demonstrating that the progression in G1 phase regardless of stimulation by EGF ended around $42 \mathrm{~h}$ and that the progression beyond this point required a mitogenic stimulation.

protein kinases, the cyclin-dependent kinase or Cdks. In mammalian cells at least $20 \mathrm{Cdks}, 5 \mathrm{Cdk}$-like protein kinases [3], and more than 30 cyclins have been identified which form multiple Cdk/cyclin complexes controlling the cell cycle progression [59] and regulating gene transcription and RNA processing [60]. Cdks become active upon binding to their regulatory and periodically expressed subunits, namely, the cyclins. Timing of activation of these complexes is determined by a variety of mechanisms including transcriptional regulation, formation of complexes between Cdks, cyclins and other regulatory partners such as Cdk inhibitors (Cdki). In addition, phosphorylation, subcellular localization, and selective proteolysis regulate the catalytic activity of these complexes.

For many years, the G0/G1 transition and progression in early G1 phase was thought to occur in a Cdk/cyclin independent manner. Following stimulation by priming factors, immediate early genes are induced at a transcriptional level by preexisting latent transcription factors such as NF- $\kappa \mathrm{B}$ [61]. While cells leave quiescence to enter G1, the phosphorylation level of pocket protein family members varies [62] and inactivation of $\mathrm{pRb}$ is shown sufficient to induce G0/G1 transition in quiescent cells [63]. Ren and Rollins postulated that hypophosphorylated or unphosphorylated $\mathrm{pRb}$ present in glioblastoma T98 G0-arrested cells may be phosphorylated by $\mathrm{Cdk} 3 /$ cyclin $\mathrm{C}$ complexes to promote entry into G1 phase [64]. However, most cells lack functional Cdk3 and no conclusive data on the ubiquitous role of $\mathrm{Cdk} 3 /$ cyclin $\mathrm{C}$ complex at the G0/G1 transition have been drawn. More recently, it was reported that $\mathrm{Cdk} 2$ interacts with cyclin $\mathrm{C}$ in early G1 $[65,66]$ to phosphorylate the transcription factor LSF (late simian virus 40 factor) [67]. Phosphorylation of LSF on serine 291 by the MEK/extracellular signalregulated kinase $(\mathrm{ERK})$ signaling pathway upon stimulation by growth factors $[58,68,69]$ in mid-late G1 phase is essential for the G1/S transition since phospho(S291)-LSF controls the transcriptional activation of the thymidylate synthase (Tyms) [70]. In contrast, phosphorylation of LSF on serine 309 inhibits LSF transactivation suggesting the required LSF shutdown in early G1 and its reactivation in late G1 mediated by Cdk/cyclin complexes and ERK, respectively [65]. This work appears important because it suggests a possible involvement of Cdk/cyclin complexes in early G1 and identifies LSF as the second known phosphorylation substrates of Cdk/cyclin complexes, in addition to $\mathrm{pRb}$, during progression from quiescence to late G1 phase (Figure 6).

The signaling pathways essential for the subsequent progression in late G1 are much more documented and clearly involve the Cdk/cyclin complexes [71]. The transition from mid- to late G1 phase is regulated by sequential phosphorylation events of members of the pocket protein 
family including the retinoblastoma protein $(\mathrm{pRb}), \mathrm{p} 107$, and p130 [62] by Cdk/cyclin complexes [4, 72]. In mid$\mathrm{G} 1$, the hypophosphorylated $\mathrm{pRb}$ is bound to the transcription factor E2F family members thereby preventing active transcription of E2F-regulated genes. The negative regulation of E2F transcription factors mediated by $\mathrm{pRb}$ occurs through a conformation structure that prevents E2F's transactivation domain to be active and probably also by recruiting chromatin-modifying enzymes repressing transcription [73]. Upon stimulation by growth factors, D-type cyclins are upregulated [74] and associate with Cdk4 and/or Cdk6 to form active complexes $[75,76]$ that partially phosphorylate $\mathrm{pRb}$ and/or actively phosphorylate a fraction of $\mathrm{pRb}$ [72]. In late G1, formation of Cdk2/cyclin $\mathrm{E}$ complex triggers additional phosphorylation of $\mathrm{pRb}$ to generate the hyperphosphorylated form of $\mathrm{pRb}$ (Figure 6) that loses the ability to repress the transactivation domain of E2F's factors [77]. Consequently, the release of E2F proteins promotes transcription of a large set of genes required for the progression in late G1 including Cdk2 and cyclin E [78, 79], $S$ phase entry [80-82] and centrosome duplication [83]. In parallel, Cdk2 phosphorylates the nuclear protein ataxiatelangiectasia implicated in the transcription of histones [84] and the nucleophosmin/B23 regulating centrosome duplication [85]. At this stage of the cell cycle progression cells have committed to DNA replication. Thus, turning on the E2F-dependent transcription coincides with the progression beyond the mitogen-dependent restriction point identified by Pardee and coworkers [49] before the discovery of Cdk/cyclin complexes.

Importantly, single or combined genetic alterations in mice of Cdk4/6-Cyclin D, Cdk2-Cyclin E, p27Kip1, and $\mathrm{Rb}$ do not affect early embryogenesis highlighting multiple compensatory mechanisms and overlapping role of these genes introducing the notion of redundancy and flexibility of the cyclin/cdks $[86,87]$ The analysis of the cell cycle in MEFs derived from these knockout mice indicated compensatory mechanism between positive and negative regulators at the G1/S transition and highlighted a complex network regulating the expression and activation of these cell cycle regulators in the progression from G1 to $S$ phase. For instance, mouse embryos lacking all interphase Cdks (Cdk2, Cdk3, Cdk4, and Cdk6) undergo organogenesis and develop up to midgestation. In these embryos, Cdk1 binds to all cyclins, resulting in the phosphorylation of the retinoblastoma protein $\mathrm{pRb}$ and the expression of genes that are regulated by E2F transcription factors [88]. Interestingly, cyclin A ablation in fibroblasts did not affect proliferation but led to prolonged expression of cyclin $\mathrm{E}$ whereas its expression is essential for cell cycle progression of hematopoietic cells and embryonic stem cells [89]. Therefore, compensatory mechanisms and overlapping role of Cdks exist but vary between cell types.

The in vivo model of regenerating liver was used for cell cycle studies since hepatocyte progression in the cell cycle is naturally synchronous with a long lasting G1-phase. Our group and others investigated Cdk2 and Cdk1 expression and activity as well as cyclin A, B, E, and D1 expression during liver regeneration [31,90-92]. Although Cdk2 is

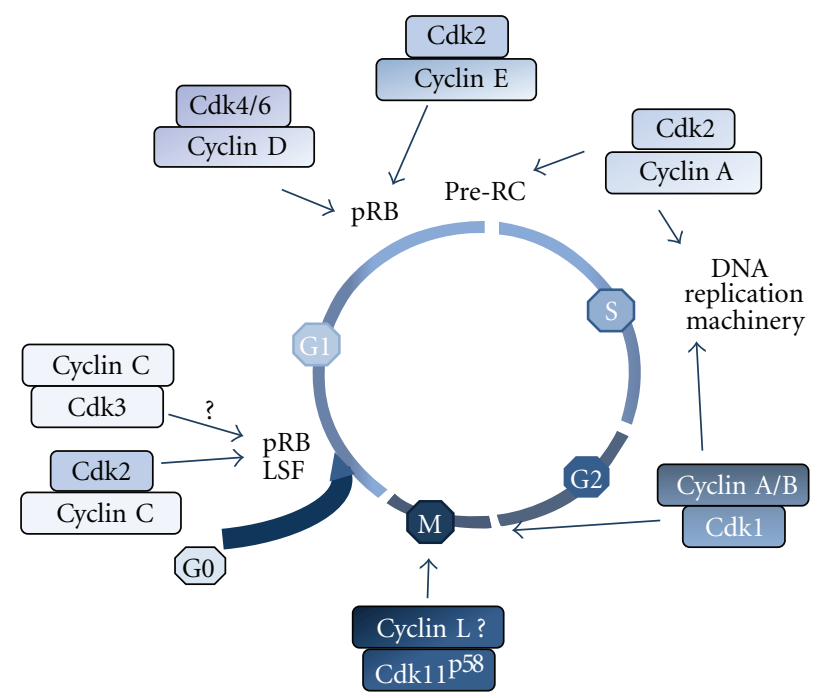

FIGURE 6: Sequential activation of Cdk/cyclin complexes throughout the cell cycle.

constantly expressed, Cdk1 is completely absent in resting hepatocytes and remains undetectable up to $20 \mathrm{~h}$ after $\mathrm{PH}$ a time corresponding to late G1 phase and G1/S transition. In quiescent hepatocytes, Jaumot et al. [93] demonstrated that cyclin D3 and Cdk4 were localized in cytoplasm whereas cyclin D1 was nuclear. Low amounts of cyclin E are found in the cytoplasm [94]. Around $13 \mathrm{~h}$ after PH, cyclins D3 and Cdk4 translocate in the nucleus and significant amounts of cyclin D1/Cdk4 and cyclin D3/Cdk4 complexes are formed but remain inactive whereas at $24 \mathrm{~h}$ they are fully active. At 13 and $24 \mathrm{~h}$, cyclin $\mathrm{E}$ is detected in both cytoplasm and nuclei. Then, the activity of Cdk 4 decreases at $28 \mathrm{~h}$ when cyclin D1 translocates to the nuclear matrix and the levels of cyclin D3 diminishes. Similarly, the inactivation of Cdk2 at $28 \mathrm{~h}$ is associated with a strong decrease in Cdk2 in the nuclear fraction and a decrease of cyclin E located in the nuclei. During this period, very low amounts of cyclin A are detected in the nuclear fraction at $13 \mathrm{~h}$ after $\mathrm{PH}$ while following its strong induction in S phase, cyclin A is present in both cytoplasm and nuclei at 24 and $28 \mathrm{~h}$. Therefore, the specific nuclear localization of the complexes is associated with their activity in liver regeneration. The maximal activity of Cdk2 detected at $24 \mathrm{~h}$ comes from cyclin E/Cdk2 and cyclin $\mathrm{A} / \mathrm{Cdk} 2$ complexes whereas the activity at $28 \mathrm{~h}$ is mainly attributable to the $\mathrm{Cdk} 2 / \mathrm{cyclin} \mathrm{A}$ heterodimer. However, the activity of Cdk2 rapidly decreases after the peak of DNA synthesis at $24 \mathrm{~h}$.

The Cdk inhibitors (Cdki's) are involved in cell cycle regulation following antagonist mitogenic and antimitogenic signals [95, 96]. Two families of Cdki's were described: the Ink4 family (p16 $6^{\text {Ink4a }}, \mathrm{p} 15^{\text {Ink4b }}, \mathrm{p} 18^{\text {Ink } 4 \mathrm{c}}$ and $\left.\mathrm{p} 19^{\text {Ink } 4 \mathrm{~d}}\right)$, which specifically bind Cdk4 and its homologue Cdk6 and the Cip/Kip family (p21 $1^{\mathrm{Cip}}, \mathrm{p} 27^{\mathrm{Kip} 1}, \mathrm{p} 27^{\mathrm{Kip} 2}$ ), which bind and inhibit the activity of a wide range of $\mathrm{Cdk} / \mathrm{cyclin}$ complexes including cyclin $\mathrm{D} / \mathrm{Cdk} 4 / 6$, cyclin $\mathrm{E} / \mathrm{Cdk} 2$, and cyclin A/Cdk2 [96]. The presence of inactive cyclin D/Cdk4 complexes during mid-G1 phase post-PH and Cyclin E/cdk2 at $28 \mathrm{~h}$ has led authors to investigate the modulation of 
Cdk kinase activities during rat liver regeneration. During rat liver regeneration, $\mathrm{p} 27^{\mathrm{Kip} 1}$ is associated with inactive cyclin D/Cdk4 complexes [93]. Furthermore, Pujol et al. [94] have demonstrated that high amounts of $\mathrm{p} 27^{\mathrm{Kip} 1}$ bind to $\mathrm{Cdk} 2 /$ cyclin $\mathrm{E}$ complexes in early and mid-G1 post-PH concomitantly with low Cdk2 kinase activities. At $24 \mathrm{~h}$, corresponding to the $\mathrm{S}$ phase, the amounts of $\mathrm{p} 27^{\mathrm{Kip} 1}$ associated to $\mathrm{Cdk} 2 /$ cyclin E decrease strongly while Cdk2 activity is maximal. Conversely, the amount of $\mathrm{p} 21^{\mathrm{Cip}}$ associated with these complexes is low during the first $13 \mathrm{~h}$ and subsequently increases. At $24 \mathrm{~h}$ low levels of both inhibitors associated with the complexes are detected, but increase in $\mathrm{p} 21^{\mathrm{Cip} 1}$ and $\mathrm{p} 27^{\mathrm{Kip} 1}$ proteins associated with $\mathrm{Cdk} 2 /$ cyclin $\mathrm{A}$ is observed at $28 \mathrm{~h}$ after the peak of hepatocyte DNA synthesis. Albrecht et al. $[97,98]$ confirmed these data and showed that expression of $\mathrm{p} 21^{\mathrm{Cip} 1}$ is induced during the prereplicative phase and is maximal after the peak of hepatocyte DNA synthesis in mice. In contrast, p $27^{\mathrm{Kip} 1}$ is present in quiescent liver and slightly induced after $\mathrm{PH}$. Immunodepletion experiments suggested that $\mathrm{p} 27^{\mathrm{Kip} 1}$ plays a role in downregulating Cdk2 activity before and after the peak of DNA replication. Interestingly, study of liver regeneration in mice lacking p $21^{\mathrm{Cip} 1}$ indicated a marked acceleration of hepatocyte progression into the cell cycle. DNA synthesis, upregulation of cyclin A and PCNA, induction of cyclin D1- and Cdk2-associated kinase activities, and appearance of the hyperphosphorylated retinoblastoma protein $(\mathrm{pRb})$ occur earlier in the $\mathrm{p} 21^{\mathrm{Cip} 1}$ knockout mice. These results demonstrate the role of $\mathrm{p} 21^{\mathrm{Cip} 1}$ in the regulation of the hepatocyte progression through G1 phase in vivo. Unexpectedly and again in contrast with the current model of mammalian cell cycle regulation, we observed that Cdk1 accumulates in S, G2, and M phase, in proliferating hepatocytes and is active during both $S$ and $M$ phases while one peak of Cdk2 activity is detected in $S$ phase only [90].

\section{Involvement of Cdk1 during the S Phase and G2/M Transition}

In eukaryotic cells, chromosomal DNA replication is ensured through periodic and tightly controlled assembly and disassembly of prereplication complexes (pre-RC) loaded on DNA replication origins $[99,100]$. In mid-late G1, the Origin Recognition Complex (ORC) containing several subunits associated to the proteins CDC6 and Cdt1 is responsible for loading a replicative helicase and the minichromosome maintenance (MCM) 2-7 subunits to form the pre-RC [100]. Interestingly, loading of the pre-RC components occurs in a low Cdk activity period [101] while at the onset of DNA synthesis the increasing Cdk-dependent kinase activities trigger the MCM complex to initiate replication and the degradation of Cdt1 to prevent reassembly of additional preRC [102-104]. The induction of MCM7 and the formation of the pre-RC thus occur in a very narrow period of time since in S phase, ORC1 and Cdt1 are degraded through several mechanisms including the phosphorylation by Cdks and downstream ubiquitination by SCFSkp2 ubiquitin Ligase $[100,105]$. These well-documented mechanisms clearly point out the crucial role of Cdk/cyclin complexes in the regulation of pre-RCs formation. Similarly, pre-RC are activated by phosphorylations involving the protein kinase Cdc7 and the Cdk2/cyclin E complex which trigger the recruitment of Cdc45 [106], a crucial docking factor for DNA helicase and polymerases. During $\mathrm{S}$ phase, the heterodimer Cdk2/cyclin A also contributes to DNA replication [107109] by phosphorylating components of the replication machinery including the Proliferating Cell Nuclear Antigen (PCNA) and DNA polymerases. The activity of Cdk2 is thus tightly associated with the entry into and progression in $\mathrm{S}$ phase (Figure 6). Following mitosis, daughter cells receive a single centrosome, which, like DNA, must duplicate prior mitosis. In early $S$ phase, centriole duplication begins and by the late G2 two mature centrosomes have been generated to ensure proper chromosome segregation [83]. Duplication of centrioles is in part regulated through the G1 phase $\mathrm{Cdk} /$ cyclin-dependent $\mathrm{pRb}$ pathway [110], and there is a large body of evidence for the $\mathrm{Cdk} 2 /$ cyclin $\mathrm{E}$ involvement in the activation by phosphorylation of crucial regulators of centriole duplication [83].

The activity of Cdk1 associated with both A- and Btype cyclins is required for entry and progression through $\mathrm{M}$ phase in all eukaryotic cells [111]. The activity of the Cdk1/cyclin B complex, which was the first cyclin-dependent kinase activity detected in sea urchin and in Xenopus [112, $113]$, rapidly appeared to be a master regulator of the G2/M transition, in all eukaryotic cells [111] including in humans cells [114]. Recently, the $\mathrm{Cdk} 11^{\mathrm{p} 58}$ protein kinase was also shown to be essential for mitosis $[115,116]$ most likely associated to the cyclin L's [117]. Because the kinase activities of Cdk2 and Cdk1 were mainly detected in G1/S and G2/M transitions respectively, they were thought to function independently at these two distinct periods without functional redundancy $[106,118]$.

This model of cell cycle control has first been challenged by the finding that some cancer cells proliferate despite Cdk2 inhibition [119]. Independently, there was a demonstration that knockout mice for Cdk2 as well as for E-type Cyclins are viable and that the cell cycle of cultured $\mathrm{Cdk} 2^{-/-}$ mouse embryonic fibroblasts (MEFs) did not show major alterations [120-122]. In addition, in the hippocampus of $\mathrm{Cdk} 2^{-/-}$mouse, the proliferation of granule neurons of the dentate gyrus which undergo continuous renewal throughout life, is not altered [123]. Similarly, hematopoiesis is not affected in Cdk2 knockout mice [124]. These data indicated that Cdk2/Cyclin E complexes were dispensable for commitment to $S$ phase. Along the same line, a Cdk1dependent compensatory mechanism regulating $S$ phase initiation and progression was also demonstrated in DT40 chicken cells lacking Cdk2 [125]. Together, these data have led authors to propose a revised model of the cell cycle control in which Cdk1 compensates for Cdk2 ablation by controlling the $\mathrm{G}_{1} / \mathrm{S}$ transition, initiation of DNA replication and centrosome duplication $[118,126]$. Interestingly, it was recently demonstrated that both $\mathrm{Cdk} 1$ and $\mathrm{Cdk} 2$ were required for efficient DNA replication in Xenopus egg extracts [127] suggesting that, at least in some nongenetically modified cell types, Cdk1 could contribute to $S$ phase initiation 
and/or DNA replication. This idea was reinforced by the observation that enforced expression of constitutively active Cdk1 mutant in HeLa cells results in abnormal origin firing and premature DNA replication in early $S$ phase and that a loss of Cdk1 activity compromised activation of late origins at late $S$ phase [103]. In this emerging picture of the cell cycle regulation, these new data probably did not profoundly affect the roles that were initially attributed to the different $\mathrm{Cdk} /$ cyclin complexes but rather introduce the notion of redundancy and flexibility $[71,128]$.

In the light of the recent findings showing compensatory involvement of Cdk1 at the G1/S transition in Cdk2 knockout mice and our data showing that Cdk1 was observed in vivo and in vitro at the G1/S transition in hepatocytes [90, 91], we have further investigated the role of Cdk1 in normal adult rat hepatocytes in the commitment to $\mathrm{S}$ phase. Cdk1 is barely detectable in quiescent hepatocytes and during G1 phase but expressed at high levels in S phase while Cdk2 is constantly expressed (Figure 2). Both Cdk1 and Cdk2, associated with cyclins A and/or B, are activated during DNA replication in regenerating rat hepatocytes [33]. We demonstrated that Cdk1 activity is twice higher than Cdk2 activity during S phase in hepatocytes. Then, knockdown experiments of Cdk1 and/or Cdk2 were performed in isolated hepatocytes and human foreskin fibroblasts (HFFs) which express high and low Cdk1 levels during $S$ phase, respectively. SiRNA-mediated repression of Cdk1 and Cdk2 significantly decreased DNA replication in hepatocytes. In HFFs, repression of Cdk2 significantly reduced the DNA synthesis while repression of Cdk1 had no effect on the rate of DNA replication but, as expected, reduced the mitotic index. In hepatocyte, the activation of Cdk1 in early $\mathrm{S}$ phase is further demonstrated by showing that hepatocytes arrested after G1/S transition prior to DNA replication by the iron chelator O-Trensox express fully active Cdk1 and Cdk2 [33]. Moreover, the decrease in DNA replication after knocking-down Cdk1 or Cdk2 silencing is not due to impaired formation of the prereplication complex since $\mathrm{Mcm} 7$ is localized in the nucleus and loaded onto chromatin. In quiescent hepatocytes, MCM7 is not expressed but its expression becomes detectable immediately after the mitogenic stimulation in mid-G1, almost concomitantly with the induction of cyclin D1 and prior the Cdk-dependent kinase activity taking place in early $\mathrm{S}$ phase. Thus, Cdk1 may be involved in the origin firing events downstream the formation of replication complexes in hepatocytes, in agreement with a recent study suggesting that cyclin A2Cdk1 might function as a transregulator of late origin firing in mammals or Cdk1 is required for proper timing of origin firing [103].

These data further support and extend the conclusion that $\mathrm{Cdk} 1$ compensates for $\mathrm{Cdk} 2$ gene ablation in genetically modified mice. Indeed, we have shown the involvement of Cdk1 in S phase of normal and nongenetically modified mammalian cells. More precisely, both Cdk1 and Cdk2 play a critical role in hepatocyte cell cycle. Consistent with our observation, Satyanarayana et al. [129] showed that the timing of $S$ phase is not altered in regenerating livers of $\mathrm{Cdk} 2^{-/-}$. Interestingly, in $\mathrm{Cdk} 2^{-/-} \mathrm{Cdk}^{+/ / \mathrm{dk} 2 \mathrm{k} 1}$ mice, in which a Cdk 2 cDNA is knocked into the $C d k 1$ locus, similar regenerative response and percentage of BrdU-positive cells are obtained compared to $\mathrm{Cdk} 2^{+/+}$mice [130]. These data indicated that Cdk2 expressed from the Cdk1 locus is able to mimic the cell function of endogenous Cdk2 and restore normal regeneration process and that one copy of $C d k 1$ is sufficient for a normal liver response after $\mathrm{PH}$. In addition, Hanse et al. [131] showed that after PH most hepatocytes enter $S$ phase in wild-type mice whereas their number is diminished significantly in $\mathrm{Cdk} 2^{-/-}$mice. In addition, hepatocytes isolated from livers of $\mathrm{cdk} 2^{-/-}$mice respond to mitogenic stimulation but to a lower extent than hepatocytes coming from wild-type mice. Very recently, Diril et al. [132] have shown that the conditional knockout of Cdk1 in adult mouse liver does not impair $S$ phase but results in DNA rereplication and a strong decrease in cytokinesis associated with an increase in Cdk2/cyclin A2 activity. The increase in ploidy and reduced cell number suggest that Cdk1 may not be directly involved in DNA replication but would regulate Cdk2 activity and termination of DNA replication and play a major role in mitosis.

Altogether, these results strengthened the conclusion that physiological hepatocyte proliferation is dependent on both Cdk1 and Cdk2. While Cdk1/cyclin E complexes are not detected in normal hepatocytes, Cdk1, cyclin A, and unexpectedly cyclin B1 are localized in the nucleus of replicating cells hepatocytes and form active complexes during $S$ phase in regenerating hepatocytes. In most mammalian cells, Cdk1/Cyclin B1 complexes localize in the cytoplasm during G2 phase [133] and are activated through a positive feedback [134] to phosphorylate cytoplasmic substrates. Then the translocation to the nucleus triggers the breakdown of nuclear envelops and mitosis. The absolute requirement of cytosolic cyclin B1 during initiation of mitosis has been proposed; however, it has also been postulated that relocating cyclin $\mathrm{B} 1$ to the nucleus in $\mathrm{S}$ phase might compromise entry into mitosis [135]. This would explain why the accumulation of nuclear Cdk1/cyclin B1 complexes during DNA replication does not trigger premature mitosis in hepatocytes. Moreover, P-Tyr15 Cdk1 found in replicating hepatocytes and known to be an inactive form of Cdk1 could also participate to this control. Noteworthy, Cdk1 is active in all hepatocytes regardless of their ploidy status, excluding a peculiar regulation or role of Cdk1 related to the tetraploidy observed in half of adult hepatocytes in rat. In addition, several data highlight the role of $\mathrm{Cdk} 2$ in hepatocyte progression and survival following acute mitogenic stimulation [131]. Moreover, the role of Cdk2 in proper DNA repair was reported [136] and strongly suggested that $\mathrm{Cdk} 2$ could be a sensor able to distinguish between moderate and extensive DNA damage to promote either survival or apoptosis. Several studies have reported that Cdk1 associated with cyclin A2 or cyclin B1 was active during $\mathrm{S}$ phase in proliferating hepatocytes. These reports are in disagreement with numerous studies demonstrating the activation and nuclear import of Cdk1 and cyclin B1 at the G2/M transition in most cell types. Further experiments are required to address whether Cdk1 and cyclin B1 exhibit 
a specific pattern of expression and activation during the cell cycle of the hepatocytes and to determine their role during $S$ phase.

\section{Extracellular Matrix Remodeling and Cdk2 Regulate Cdk1 Expression and Activation}

In normal liver, adult hepatocytes quiescent and normally do not undergo cell division but keep the ability to proliferate in response to toxic injury and infection. In regenerating liver, most of the hepatocytes undergo cell division while maintaining their metabolic function and tissue architecture. This process involved a multitude of cellular processes including at early stage acute-phase reaction [12], induction of proangiogenic signals [137], and an important extracellular matrix (ECM) breakdown and remodeling [138] leading to transient changes in the liver architecture. Connective tissue is found around the portal triads whereas reticular fibers and small amounts of basement membrane are present between the sinusoid endothelial cells and the hepatocytes. In the portal areas, mainly type I, III and V collagens are found while type IV collagen, laminin, entactin, and nidogen form the basement membrane along the sinusoids. Fibronectin is also present in the space of Disse [139].

Some proteins involved in the structural integrity of the liver are also required for normal regeneration. For example, deficiencies in connexin-32, a gap-junction protein [140], and keratin-8, an intermediate filament forming protein [141], lead to extended liver damage after partial hepatectomy. Connexin-32 is also required for normal mitosis by mediating cellular connections during cell division. Loss of proteases also results in prolonged liver injury. Mice lacking genes encoding the serine proteases urokinase-type plasminogen activator (uPA) and tissue-type plasminogen activator (tPA) exhibit delayed regeneration whereas the deficiency of the plasminogen inhibitors leads to accelerated liver regeneration [142, 143]. Interestingly, injection or increased expression of collagenase in intact liver, associated with HGF or TGF $\alpha$, induces hepatocyte proliferation, suggesting that ECM degradation could contribute to hepatocyte priming [144]. Conversely, Issa et al. [145] observed that failure in collagen-I degradation in mouse liver inhibits the hepatocyte proliferation response. In rat, activation of plasminogen to plasmin begins shortly after $\mathrm{PH}$ and stays pronounced until 3-6h. Successive inductions of mRNA levels of the metalloproteinases (MMP)-9, MMP-2, MMP-13, MMP-14, MMP-24, involved in matrix remodeling in both normal and pathological processes, are observed in mouse. Moreover, inhibitors of metalloproteinases (TIMP)-3, TIMP-4, TIMP1 are also upregulated. In particular, TIMP-1 expression is induced prior the onset of DNA synthesis in rat and mouse models [146, 147]. After PH, its activation is linked to the hepatocyte cell cycle since experiments based on gain of TIMP-1 function in transgenic mice result in delayed cell cycle progression whereas loss of function in knockout mice accelerates liver regeneration [147]. Activation of MMP9 after $\mathrm{PH}$, mediated by plasmin or by plasmin-activated MMP-3, is followed by activation of pro-MMP-2 in MMP2 probably by the membrane-type $1 \mathrm{MMP}$. In early phases of the liver regeneration, MMP-9 is located in the immediate periportal hepatocytes, then, its localization extends rapidly throughout the lobule before decreasing at $72 \mathrm{~h}$ post-PH. In the meantime, MMP-2 expression enhances in the hepatocytes at 24 and $48 \mathrm{~h}$ after hepatectomy [148]. Interestingly, migration of the MMP's staining pattern correlates with the gradual hepatocyte progression into the cell cycle from the periportal to the pericentral areas. This could be related to an important regulatory mechanism for controlling cell proliferation through the proteolytic maturation and/or liberation of priming and growth factors during ECM remodeling. In accordance, mature HGF production is delayed by $12 \mathrm{~h}$ in the $\mathrm{uPA}^{-/-}$mice along with a delayed DNA synthesis. Loss of uPA results in decreased plasmin levels responsible for activating MMP that in turn digest the ECM and allow release of activated growth factors like HGF from ECM [149]. Deletion of the mouse gene Timp3 results in the increase in TNF- $\alpha$ converting enzyme activity (TACE), constitutive release of TNF $\alpha$ and activation of TNF $\alpha$-dependent signaling in the liver. In mice lacking Timp3 gene, cyclin D1 and PCNA expression as well as hepatocyte division occur earlier than in wild-type mice with a shortened cell cycle. However, these mice succumbed of liver failure by a TNF $\alpha$-signalingdependent cell death demonstrating also the importance of TIMP-3 in controlling TNF $\alpha$ bioavailability [150].

Studies performed in vitro have shown that $\mathrm{TNF} \alpha$ induces MMP-9 expression in mouse hepatocytes [151] and that MMP-9 transcription involves activation of NF- $\kappa \mathrm{B}$ pathway [152]. Cytokine-specific regulation of MMP/TIMP expression in hepatic stellate cells also suggests that the initial matrix degradation during liver injury might be enhanced by TNF $\alpha$, while diminished matrix degradation during chronic tissue injury might be due to the action of TGF- $\beta 1$ through TIMP induction [153]. Together, these studies clearly demonstrated the importance in matrix remodeling to promote proliferation of adult hepatocytes. This conclusion is reinforced by the observation that normal rat hepatocytes plated on denatured collagen I are able to proliferate following stimulation by EGF while they do not respond to this growth factor when plated on native collagen I gel [154], collagen sandwich [155], or matrigel [156]. To further address the role of the extracellular matrix degradation to promote cell cycle entry and progression of differentiated adult hepatocytes following stimulation by mitogenic signals, the primary pure culture of hepatocytes did not appear as a pertinent model since hepatocytes progress regardless of priming factors in this model. In addition, we had previously shown that very low amounts of ECM were synthesized in pure culture. We therefore used quiescent adult rat hepatocytes in coculture with liver biliary epithelial cells (Figure 7). Indeed, as mentioned above, hepatocytes in cocultures are stably differentiated for several weeks and capable of extracellular matrix deposition. This ECM located around the hepatocyte cords contains high amounts of type III, I collagens and fibronectin as in vivo [36]. Moreover, cytoskeleton organization of hepatocytes is similar in coculture and in vivo with a localization of the cytokeratins beneath of the plasma membrane $[35,157]$ and bile canaliculi structures present between the hepatocytes are 


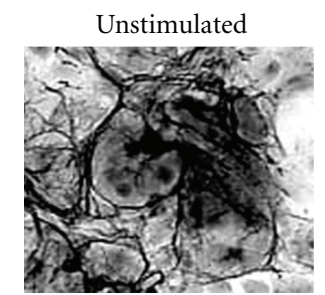

TNF $\alpha$
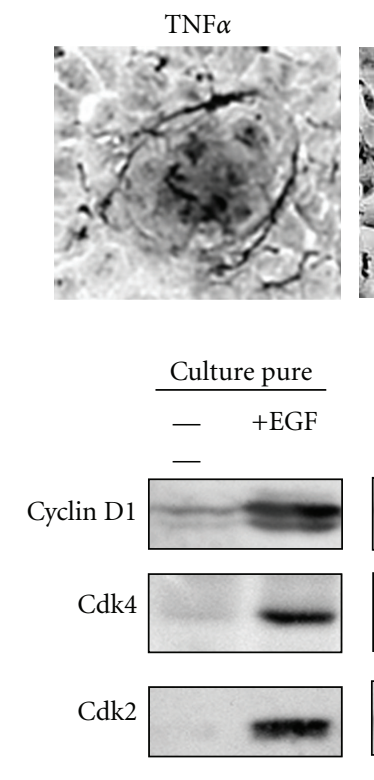

Cdk1

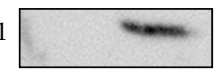

Histone $\mathrm{H} 1$

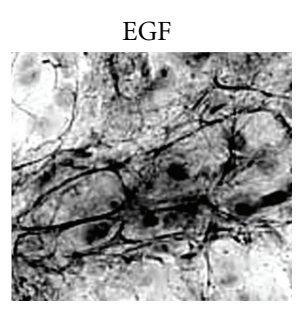

$\mathrm{TNF} \alpha / \mathrm{EGF}$
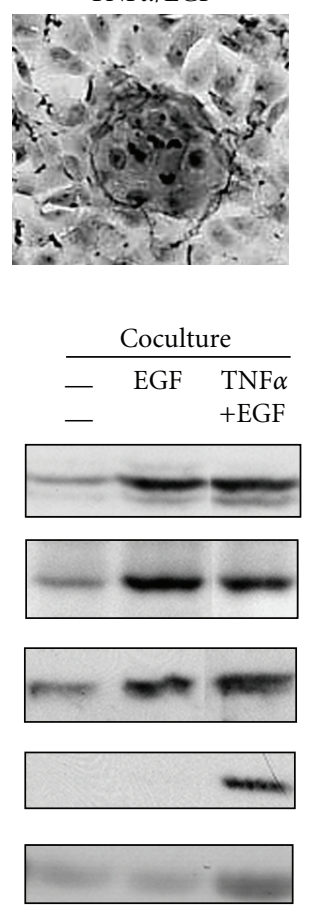

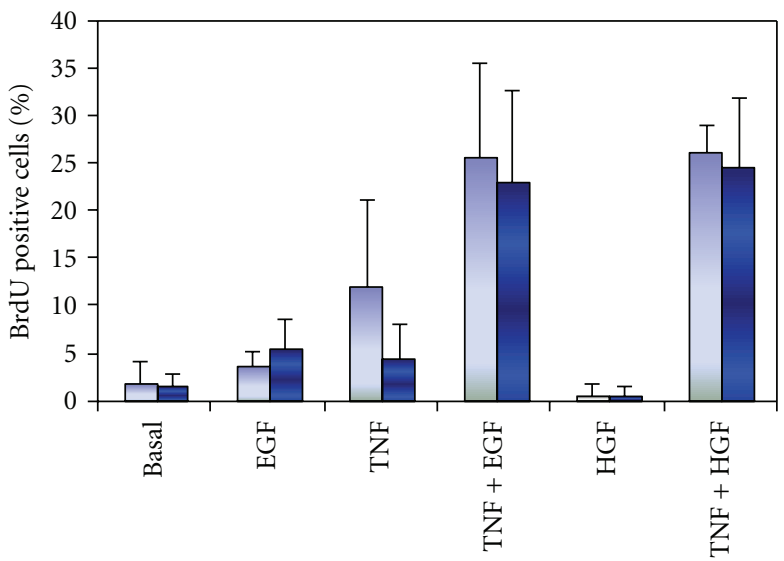

FIGURE 7: Upper left panel: detection of the extracellular matrix using the reticulin staining in unstimulated and EGF, TNF $\alpha$ or TNF $\alpha+$ EGF stimulated rat hepatocytes. Upper right panel: detection of BrdU positive hepatocytes in cocultured hepatocytes 3 days after stimulation with EGF, TNF $\alpha$, HGF or combination of TNF $\alpha$ and EGF or HGF. Basal condition: unstimulated cells. Light blue: without fetal calf serum, dark blue: with fetal calf serum. Lower panel: expression of Cdks and cyclins in cultured rat hepatocytes. Cyclin D1, Cdk4, Cdk2, and Cdk1 were analyzed by western blotting. In addition, kinase activities of Cdk1 and Cdk2 were measured using histone $\mathrm{H} 1$ as a substrate.

also functional. Using this coculture system, we established new conditions allowing rat hepatocytes to undergo several proliferation waves (Figure 7) without loss of differentiation in presence of the priming cytokine, $\mathrm{TNF} \alpha$, and growth factors, such as HGF, EGF as observed in vivo during liver regeneration [39].

This model of controlled induction of hepatocyte proliferation has been crucial to define whether the signaling mechanisms induced by TNF $\alpha$ could be linked to ECM remodeling (Figure 7). The quantification of ECM deposition detected using reticulin staining on cells stimulated by EGF alone, TNF $\alpha /$ EGF, or successively by EGF and then TNF $\alpha$ revealed several crucial data: (1) ECM is very abundant in both unstimulated and EGF-treated cells, (2) in TNF $\alpha / E G F-t r e a t e d$ cocultures, ECM deposition is very sparse and most fibers disappear within colonies of proliferating hepatocytes, (3) TNF $\alpha$ stimulation, before or after EGF exposure, induces ECM degradation, (4) during prolonged TNF $\alpha /$ EGF stimulation, DNA synthesis decreases concomitantly with new ECM deposition. In addition, the phenanthroline, a specific inhibitor of MMP activities reduces the TNF $\alpha$-mediated ECM degradation resulting in the decrease in DNA replication. Additional experiments further demonstrated that the ECM degradation was due to the NF- $\kappa \mathrm{B}$-mediated induction of MMP-9 expression by $\mathrm{TNF} \alpha$ [39]. Thus, ECM proteolysis controlled by $\mathrm{TNF} \alpha$ via activation of the NF- $\kappa \mathrm{B}$ pathway and induction of MMP-9 is necessary for $S$ phase entry in hepatocytes. This ECM remodeling signal is also required for initiating any subsequent hepatocyte division wave in presence of mitogen [39]. These observations have been confirmed by Olle and coworkers using MMP-9-/- mice [158]. Indeed, in these animals hepatic regenerative response is delayed compared with wild-type control animals. Moreover, they express significantly less HGF and TNF $\alpha$ at day 2 post$\mathrm{PH}$ corresponding to hepatocyte DNA synthesis in mice [158]. In addition, in hepatoma cells, TNF $\alpha$ stimulates DNA replication by causing release of TGF $\alpha$ into the culture medium through the metalloproteinase disintegrin TACE. Then, TGF $\alpha$ activates EGFR and multiple downstream intracellular signaling cascades required for DNA replication [159]. 
Using both pure culture of hepatocytes and the coculture model, we compared expression of cell cycle markers to further investigate the molecular pathways involved in the progression in late G1 phase. In unstimulated cocultures, cyclin D1 and Cdk2 are barely detectable (Figure 7). This pattern of expression, similar to that observed in unstimulated primary pure cultures of hepatocytes, suggested that they are blocked in G1 upstream the mitogen restriction point. Unexpectedly, although no BrdU-positive hepatocytes are detected in EGF-stimulated co-cultures, cyclin D1, Cdk4, and Cdk2 accumulate in this culture condition. Interestingly, even if Cdk2 was present, no histone $\mathrm{H} 1$ kinase activity is detected (Figure 7). Therefore, EGF alone promotes the progression beyond the mitogen restriction point in late G1 although cells arrest before $S$ phase. Our results could be linked to previous reports showing that cyclin E and Cdk2 are present in cells plated on denatured collagen film, while hepatocytes plated on collagen gel do not proliferate and lack the Cdk2 activity [154]. Moreover, both Cdk2 and Cdk1 are active. We therefore point out a new cell cycle control in late G1 associated with ECM deposition and overcome by $\mathrm{TNF} \alpha$ addition that triggers ECM remodeling and induction of MMP9. Importantly, TNF $\alpha$ stimulation following EGF exposition induces the expression of Cdk1 and the activation of both Cdk2 and Cdk1 kinase activities. Altogether, our results show that induction of Cdk1, correlating with the hepatocyte $\mathrm{S}$ phase entry, requires remodeling of the extracellular matrix and induction of the metalloproteinase MMP9 by TNF $\alpha$ stimulation. They also suggest that catalytic activation of Cdk1 may be regulated by Cdk2 kinase activity. This led us to draw the conclusion that Cdk2 and Cdk1 would exhibit a sequential catalytic activation under the control of extracellular signals including cytokines, growth factors as well as extracellular matrix remodeling. TNF $\alpha-$ mediated ECM remodeling is necessary for Cdk2 activity, Cdk1 expression, G1/S transition, and completion of the cell cycle of hepatocytes in co-cultures.

\section{Conclusion}

Altogether, our laboratory and others have demonstrated the concomitant expression and activation of both Cdk1 and Cdk2 during $S$ phase in hepatocytes and their active contribution to the DNA replication. Finally, we show that Cdk1 expression and activation are correlated to ECM degradation via the involvement of the proinflammatory cytokine TNF $\alpha$. We thus identified for the first time a new signaling pathway regulating Cdk1 expression at the G1/S transition upon stimulation by cytokines. The peculiar biphasic pattern of Cdk1 activity during cell cycle of normal hepatocytes and the evenly active Cdk1 and Cdk2 during S phase contrasts with most mammalian cell types in which active Cdk2 is highly predominant over other Cdks in S phase. In most cell types, the low levels of expression and activation of Cdk1 in S phase led to the conclusion that Cdk1 and Cdk2 were functionally exclusive with specific functions in G2/M and G1/S transitions, respectively. However, in absence of Cdk2, Cdk1 can fully compensate for S phase function of Cdk2 but fails to compensate for Cdk2's DNA repair functions in mammalian cells. Based on the data obtained by our laboratory and others, we hypothesize that those high levels of active Cdk1 and Cdk2 following G1/S transition could participate to cellular defense response following stress stimulus in controlling rapid DNA repair and synthesis. We also showed that Cdk1 expression and activation are correlated to ECM degradation via the involvement of the proinflammatory cytokine TNF $\alpha$. We thus identified for the first time a new signaling pathway regulating Cdk1 expression at the G1/S transition upon stimulation by cytokines. It also further confirms the wellorchestrated regulation of liver regeneration via multiple extracellular signals and pathways. Several important questions remain unanswered. How does TNF $\alpha$ induce Cdk2 kinase activity? It could be hypothesized that low levels of the Cdk inhibitor p27 $7^{\text {Kip } 1}$ following TNF $\alpha$ stimulation favors activation of Cdk2/cyclin E and Cdk2/cyclin A kinase activities. In addition, the mechanism by which TNF $\alpha$ induces Cdk1 expression remains unclear. Does it involve a transcriptional regulation mediated by unidentified signaling pathways and transcription factors? Local remodeling of the ECM could lead to disruption of ECM-cell communications achieved by integrins. Through multiple protein-protein interactions and signaling events, they could activate various signaling cascades regulating transcriptional activities. For example, repression of integrin-linked kinase (ILK), a cellECM-adhesion component implicated in cell-ECM signaling via the integrins, leads to enhanced cell proliferation and hepatomegaly [160].

\section{Abbreviations}
H: Hours;
LDH: Lactate deshydrogenase
EGF: Epidermal growth factor
ECM: Extracellular matrix
TGF $\alpha$ : Transforming growth factor alpha
TNF $\alpha$ : Tumor necrosis factor alpha
HGF: Hepatocyte growth factor
Cdk: Cyclin-dependent kinase.

\section{Acknowledgments}

The authors thank Drs. Anne-Laure Serandour and Delphine Garnier for their involvement in some of the experiments described in this paper and all the members of the team "Stress, Defences and Regeneration" from the laboratory Inserm UMR_S 991. Our team is financially supported by federal funding through Inserm, CNRS, and the University of Rennes1 and the European grant, Liv-ES, FP7 program, Health F5-2008-223317, the FEDER (Fonds européen de développement régional) and the "Contrat plan état région" (axe biothérapie).

\section{References}

[1] H. Araki, "Cyclin-dependent kinase-dependent initiation of chromosomal DNA replication," Current Opinion in Cell Biology, vol. 22, no. 6, pp. 766-771, 2010. 
[2] V. R. Iyer, M. B. Eisen, D. T. Ross et al., "The transcriptional program in the response of human fibroblasts to serum," Science, vol. 283, no. 5398, pp. 83-87, 1999.

[3] M. Malumbres, E. Harlow, T. Hunt et al., "Cyclin-dependent kinases: a family portrait," Nature Cell Biology, vol. 11, no. 11, pp. 1275-1276, 2009.

[4] C. J. Sherr, "Mammalian G1 cyclins and cell cycle progression," Proceedings of the Association of American Physicians, vol. 107, no. 2, pp. 181-186, 1995.

[5] M. Knockaert, P. Greengard, and L. Meijer, "Pharmacological inhibitors of cyclin-dependent kinases," Trends in Pharmacological Sciences, vol. 23, no. 9, pp. 417-425, 2002.

[6] F. Ajchenbaum, K. Ando, J. A. DeCaprio, and J. D. Griffin, "Independent regulation of human D-type cyclin gene expression during G1 phase in primary human T lymphocytes," Journal of Biological Chemistry, vol. 268, no. 6, pp. 4113-4119, 1993.

[7] H. A. Coller, L. Sang, and J. M. Roberts, "A new description of cellular quiescence," PLoS Biology, vol. 4, no. 3, article e83, 2006.

[8] L. Sang, H. A. Coller, and J. M. Roberts, "Control of the reversibility of cellular quiescence by the transcriptional repressor HES1," Science, vol. 321, no. 5892, pp. 1095-1100, 2008.

[9] R. Bruck, H. Aeed, H. Shirin et al., "The hydroxyl radical scavengers dimethylsulfoxide and dimethylthiourea protect rats against thioacetamide-induced fulminant hepatic failure," Journal of Hepatology, vol. 31, no. 1, pp. 27-38, 1999.

[10] A. Panduro, F. Shalaby, F. R. Weiner, L. Biempica, M. A. Zern, and D. A. Shafritz, "Transcriptional switch from albumin to $\alpha$-fetoprotein and changes in transcription of other genes during carbon tetrachloride induced liver regeneration," Biochemistry, vol. 25, no. 6, pp. 1414-1420, 1986.

[11] G. K. Michalopoulos and M. DeFrances, "Liver regeneration," Advances in Biochemical Engineering/Biotechnology, vol. 93, pp. 101-134, 2005.

[12] N. Fausto, J. S. Campbell, and K. J. Riehle, "Liver regeneration," Hepatology, vol. 43, no. 2, pp. S45-S53, 2006.

[13] H. M. Rabes, R. Wirsching, H. V. Tuczek, and G. Iseler, "Analysis of cell cycle compartments of hepatocytes after partial hepatectomy," Cell and Tissue Kinetics, vol. 9, no. 6, pp. 517-532, 1976.

[14] F. L. Moolten and N. L. R. Bucher, "Regeneration of rat liver: transfer of humoral agent by cross circulation," Science, vol. 158, no. 3798, pp. 272-274, 1967.

[15] E. M. Webber, J. Bruix, R. H. Pierce, and N. Fausto, "Tumor necrosis factor primes hepatocytes for DNA replication in the rat," Hepatology, vol. 28, no. 5, pp. 1226-1234, 1998.

[16] D. E. Cressman, L. E. Greenbaum, R. A. DeAngelis et al., "Liver failure and defective hepatocyte regeneration in interleukin-6- deficient mice," Science, vol. 274, no. 5291, pp. 1379-1383, 1996.

[17] J. C. Hsu, R. Bravo, and R. Taub, "Interactions among LRF-1, JunB, c-Jun, and c-Fos define a regulatory program in the G1 phase of liver regeneration," Molecular and Cellular Biology, vol. 12, no. 10, pp. 4654-4665, 1992.

[18] J. W. Grisham, "A morphologic study of deoxyribonucleic acid synthesis and cell proliferation in regenerating rat liver; autoradiography with thymidine-H3," Cancer Research, vol. 22, pp. 842-849, 1962.

[19] J. I. Fabrikant, "The kinetics of cellular proliferation in regenerating liver," Journal of Cell Biology, vol. 36, no. 3, pp. $551-565,1968$.
[20] J. J. Widmann and H. D. Fahimi, "Proliferation of mononuclear phagocytes (Kupffer cells) and endothelial cells in regenerating rat liver. A light and electron microscopic cytochemical study," American Journal of Pathology, vol. 80, no. 3, pp. 349-366, 1975.

[21] J. Serratosa, J. Domingo, C. Enrich, and O. Bachs, "Nuclear growth and chromatin relaxation-condensation cycle in hepatocytes during the proliferative activation of rat liver," Virchows Archiv Abteilung B, vol. 55, no. 1, pp. 57-64, 1988.

[22] N. Agell, M. J. Pujol, A. Lopez-Girona, M. Bosch, J. L. Rosa, and O. Bachs, "Calmodulin expression during rat liver regeneration,” Hepatology, vol. 20, no. 4 I, pp. 1002-1008, 1994.

[23] P. L. Etienne, G. Baffet, B. Desvergne, M. Boisnard-Rissel, D. Glaise, and C. Guguen-Guillouzo, "Transient expression of cfos and constant expression of c-myc in freshly isolated and cultured normal adult rat hepatocytes," Oncogene Research, vol. 3, no. 3, pp. 255-262, 1988.

[24] P. Loyer, G. Ilyin, S. Cariou, D. Glaise, A. Corlu, and C. Guguen-Guillouzo, "Progression through G1 and S phases of adult rat hepatocytes," Progress in Cell Cycle Research, vol. 2, pp. 37-47, 1996.

[25] M. P. López-García and S. M. Sanz-González, "Peroxynitrite generated from constitutive nitric oxide synthase mediates the early biochemical injury in short-term cultured hepatocytes," FEBS Letters, vol. 466, no. 1, pp. 187-191, 2000.

[26] A. J. Paine and E. Andreakos, "Activation of signalling pathways during hepatocyte isolation: relevance to toxicology in vitro," Toxicology in Vitro, vol. 18, no. 2, pp. 187-193, 2004.

[27] N. Fausto, "Liver regeneration," Journal of Hepatology, vol. 32, no. 1, pp. 19-31, 2000.

[28] Y. M. Kim, M. E. De Vera, S. C. Watkins, and T. R. Billiar, "Nitric oxide protects cultured rat hepatocytes from tumor necrosis factor- $\alpha$-induced apoptosis by inducing heat shock protein 70 expression," Journal of Biological Chemistry, vol. 272, no. 2, pp. 1402-1411, 1997.

[29] B. Bailly-Maitre, G. de Sousa, N. Zucchini, J. Gugenheim, K. E. Boulukos, and R. Rahmani, "Spontaneous apoptosis in primary cultures of human and rat hepatocytes: molecular mechanisms and regulation by dexamethasone," Cell Death and Differentiation, vol. 9, no. 9, pp. 945-955, 2002.

[30] D. Gilot, P. Loyer, A. Corlu et al., "Liver protection from apoptosis requires both blockage of initiator caspase activities and inhibition of ASK1/JNK pathway via glutathione Stransferase regulation," Journal of Biological Chemistry, vol. 277, no. 51, pp. 49220-49229, 2002.

[31] X. P. Lu, K. S. Koch, D. J. Lew et al., "Induction of cyclin mRNA and cyclin-associated histone H1 kinase during liver regeneration," Journal of Biological Chemistry, vol. 267, no. 5, pp. 2841-2844, 1992.

[32] P. Loyer, S. Cariou, D. Glaise, M. Bilodeau, G. Baffet, and C. Guguen-Guillouzo, "Growth factor dependence of progression through G1 and S phases of adult rat hepatocytes in vitro: evidence of a mitogen restriction point in mid-late G1," Journal of Biological Chemistry, vol. 271, no. 19, pp. 11484-11492, 1996.

[33] D. Garnier, P. Loyer, C. Ribault, C. Guguen-Guillouzo, and A. Corlu, "Cyclin-dependent kinase 1 plays a critical role in DNA replication control during rat liver regeneration," Hepatology, vol. 50, no. 6, pp. 1946-1956, 2009.

[34] C. Guguen Guillouzo, B. Clement, and G. Baffet, "Maintenance and reversibility of active albumin secretion by adult rat hepatocytes co-cultured with another liver epithelial cell 
type," Experimental Cell Research, vol. 143, no. 1, pp. 47-54, 1983.

[35] A. Corlu, B. Kneip, C. Lhadi et al., "A plasma membrane protein is involved in cell contact-mediated regulation of tissue-specific genes in adult hepatocytes," Journal of Cell Biology, vol. 115, no. 2, pp. 505-515, 1991.

[36] B. Clement, C. Guguen-Guillouzo, and J. P. Campion, "Long-term co-cultures of adult human hepatocytes with rat liver epithelial cells: modulation of albumin secretion and accumulation of extracellular material," Hepatology, vol. 4, no. 3, pp. 373-380, 1984.

[37] J. M. Fraslin, B. Kneip, S. Vaulont, D. Glaise, A. Munnich, and C. Guguen-Guillouzo, "Dependence of hepatocyte-specific gene expression on cell-cell interactions in primary culture," EMBO Journal, vol. 4, no. 10, pp. 2487-2491, 1985.

[38] A. Corlu, G. Ilyin, S. Cariou, I. Lamy, P. Loyer, and C. Guguen-Guillouzo, "The coculture: a system for studying the regulation of liver differentiation/proliferation activity and its control," Cell Biology and Toxicology, vol. 13, no. 4-5, pp. 235-242, 1997.

[39] A. L. Sérandour, P. Loyer, D. Garnier et al., "TNF $\alpha$-mediated extracellular matrix remodeling is required for multiple division cycles in rat hepatocytes," Hepatology, vol. 41, no. 3, pp. 478-486, 2005.

[40] H. A. Iocca and H. C. Isom, "Tumor necrosis factor- $\alpha$ acts as a complete mitogen for primary rat hepatocytes," American Journal of Pathology, vol. 163, no. 2, pp. 465-476, 2003.

[41] A. B. Pardee, "A restriction point for control of normal animal cell proliferation," Proceedings of the National Academy of Sciences of the United States of America, vol. 71, no. 4, pp. 1286-1290, 1974.

[42] W. J. Pledger, C. D. Stiles, H. N. Antoniades, and C. D. Scher, "Induction of DNA synthesis in BALB/c 3T3 cells by serum components: reevaluation of the commitment process," Proceedings of the National Academy of Sciences of the United States of America, vol. 74, no. 10, pp. 4481-4485, 1977.

[43] W. J. Pledger, C. D. Stiles, H. N. Antoniades, and C. D. Scher, "An ordered sequence of events is required before BALB/c3T3 cells become committed to DNA synthesis," Proceedings of the National Academy of Sciences of the United States of America, vol. 75, no. 6, pp. 2839-2843, 1978.

[44] D. T. Denhardt, D. R. Edwards, and C. L. J. Parfett, "Gene expression during the mammalian cell cycle," Biochimica et Biophysica Acta, vol. 865, no. 2, pp. 83-125, 1986.

[45] F. Cross, J. Roberts, and H. Weintraub, "Simple and complex cell cycles," Annual Review of Cell Biology, vol. 5, pp. 341-395, 1989.

[46] E. B. Leof, J. J. Van Wyk, E. J. O'Keefe, and W. J. Pledger, "Epidermal growth factor (EGF) is required only during the traverse of early G1 in PDGF stimulated density-arrested BALB/c-3T3 cells," Experimental Cell Research, vol. 147, no. 1, pp. 202-208, 1983.

[47] H. C. Yang and A. B. Pardee, "Insulin-like growth factor I regulation of transcription and replicating enzyme induction necessary for DNA synthesis," Journal of Cellular Physiology, vol. 127, no. 3, pp. 410-416, 1986.

[48] A. B. Pardee, "Biochemical and molecular events regulating cell proliferation," The Journal of Pathology, vol. 149, no. 1, pp. 1-2, 1986.

[49] A. B. Pardee, "G1 events and regulation of cell proliferation," Science, vol. 246, no. 4930, pp. 603-608, 1989.
[50] S. I. Reed, "The role of p34 kinases in the G1 to S-phase transition," Annual Review of Cell Biology, vol. 8, pp. 529-561, 1992.

[51] J. A. McGowan and N. L. R. Bucher, "Pyruvate promotion of DNA synthesis in serum-free primary cultures of adult rat hepatocytes," In Vitro, vol. 19, no. 3, pp. 159-166, 1983.

[52] N. Sawada, "Hepatocytes from old rats retain responsiveness of c-myc expression to EGF in primary culture but do not enter S phase," Experimental Cell Research, vol. 181, no. 2, pp. 584-588, 1989.

[53] J. H. Albrecht, M. Y. Hu, and F. B. Cerra, "Distinct patterns of cyclin D1 regulation in models of liver regeneration and human liver," Biochemical and Biophysical Research Communications, vol. 209, no. 2, pp. 648-655, 1995.

[54] H. Talarmin, C. Rescan, S. Cariou et al., "The mitogenactivated protein kinase kinase/extracellular signal- regulated kinase cascade activation is a key signalling pathway involved in the regulation of $\mathrm{G} 1$ phase progression in proliferating hepatocytes," Molecular and Cellular Biology, vol. 19, no. 9, pp. 6003-6011, 1999.

[55] C. J. Nelsen, D. G. Rickheim, M. M. Tucker, L. K. Hansen, and J. H. Albrecht, "Evidence that cyclin D1 mediates both growth and proliferation downstream of TOR in hepatocytes," Journal of Biological Chemistry, vol. 278, no. 6, pp. 3656-3663, 2003.

[56] A. Natarajan, B. Wagner, and M. Sibilia, "The EGF receptor is required for efficient liver regeneration," Proceedings of the National Academy of Sciences of the United States of America, vol. 104, no. 43, pp. 17081-17086, 2007.

[57] S. Ussar and T. Voss, "MEK1 and MEK2, different regulators of the G1/S transition," Journal of Biological Chemistry, vol. 279, no. 42, pp. 43861-43869, 2004.

[58] J. V. Ruderman, "MAP kinase and the activation of quiescent cells," Current Opinion in Cell Biology, vol. 5, no. 2, pp. 207213, 1993.

[59] M. Malumbres and M. Barbacid, "Mammalian cyclindependent kinases," Trends in Biochemical Sciences, vol. 30, no. 11, pp. 630-641, 2005.

[60] P. Loyer, J. H. Trembley, R. Katona, V. J. Kidd, and J. M. Lahti, "Role of CDK/cyclin complexes in transcription and RNA splicing," Cellular Signalling, vol. 17, no. 9, pp. 1033-1051, 2005.

[61] M. J. FitzGerald, E. M. Webber, J. R. Donovan, and N. Fausto, "Rapid DNA binding by nuclear factor $\kappa \mathrm{B}$ in hepatocytes at the start of liver regeneration," Cell Growth and Differentiation, vol. 6, no. 4, pp. 417-427, 1995.

[62] J. A. DeCaprio, Y. Furukawa, F. Ajchenbaum, J. D. Griffin, and D. M. Livingston, "The retinoblastoma-susceptibility gene product becomes phosphorylated in multiple stages during cell cycle entry and progression," Proceedings of the National Academy of Sciences of the United States of America, vol. 89, no. 5, pp. 1795-1798, 1992.

[63] A. J. Canhoto, A. Chestukhin, L. Litovchick, and J. A. DeCaprio, "Phosphorylation of the retinoblastoma-related protein p130 in growth-arrested cells," Oncogene, vol. 19, no. 44, pp. 5116-5122, 2000.

[64] S. Ren and B. J. Rollins, "Cyclin C/Cdk3 promotes Rbdependent G0 exit," Cell, vol. 117, no. 2, pp. 239-251, 2004.

[65] U. Hansen, L. Owens, and U. H. Saxena, "Transcription factors LSF and E2Fs: tandem cyclists driving G0 to S?" Cell Cycle, vol. 8, no. 14, pp. 2146-2151, 2009.

[66] U. H. Saxena, C. M. H. Powell, J. K. Fecko et al., "Phosphorylation by cyclin C/Cyclin-dependent kinase 2 following 
mitogenic stimulation of murine fibroblasts inhibits transcriptional activity of LSF during G1 progression," Molecular and Cellular Biology, vol. 29, no. 9, pp. 2335-2345, 2009.

[67] C. H. Kim, C. Heath, A. Bertuch, and U. Hansen, "Specific stimulation of simian virus 40 late transcription in vitro by a cellular factor binding the simian virus 40 21-basepair repeat promoter element," Proceedings of the National Academy of Sciences of the United States of America, vol. 84, no. 17, pp. 6025-6029, 1987.

[68] Z. Pagon, J. Volker, G. M. Cooper, and U. Hansen, "Mammalian transcription factor LSF is a target of ERK signaling," Journal of Cellular Biochemistry, vol. 89, no. 4, pp. 733-746, 2003.

[69] J. L. Volker, L. E. Rameh, Q. Zhu, J. DeCaprio, and U. Hansen, "Mitogenic stimulation of resting $\mathrm{T}$ cells causes rapid phosphorylation of the transcription factor LSF and increased DNA-binding activity," Genes and Development, vol. 11, no. 11, pp. 1435-1446, 1997.

[70] C. M. H. Powell, T. L. Rudge, Q. Zhu, L. F. Johnson, and U. Hansen, "Inhibition of the mammalian transcription factor LSF induces S-phase-dependent apoptosis by downregulating thymidylate synthases expression," EMBO Journal, vol. 19, no. 17, pp. 4665-4675, 2000.

[71] A. Satyanarayana and P. Kaldis, "Mammalian cell-cycle regulation: several cdks, numerous cyclins and diverse compensatory mechanisms," Oncogene, vol. 28, no. 33, pp. 29252939, 2009.

[72] J. Kato, H. Matsushime, S. W. Hiebert, M. E. Ewen, and C. J. Sherr, "Direct binding of cyclin D to the retinoblastoma gene product $(\mathrm{pRb})$ and $\mathrm{pRb}$ phosphorylation by the cyclin D-dependent kinase CDK4," Genes and Development, vol. 7, no. 3, pp. 331-342, 1993.

[73] J. M. Trimarchi and J. A. Lees, "Sibling rivalry in the E2F family," Nature Reviews Molecular Cell Biology, vol. 3, no. 1, pp. 11-20, 2002.

[74] H. Matsushime, M. F. Roussel, R. A. Ashmun, and C. J. Sherr, "Colony-stimulating factor 1 regulates novel cyclins during the G1 phase of the cell cycle," Cell, vol. 65, no. 4, pp. 701$713,1991$.

[75] H. Matsushime, M. E. Ewen, D. K. Strom et al., "Identification and properties of an atypical catalytic subunit (p34(PSK- J3)/cdk4) for mammalian D type G1 cyclins," Cell, vol. 71, no. 2, pp. 323-334, 1992.

[76] H. Matsushime, D. E. Quelle, S. A. Shurtleff, M. Shibuya, C. J. Sherr, and J. Y. Kato, "D-type cyclin-dependent kinase activity in mammalian cells," Molecular and Cellular Biology, vol. 14, no. 3, pp. 2066-2076, 1994.

[77] A. S. Lundberg and R. A. Weinberg, "Functional inactivation of the retinoblastoma protein requires sequential modification by at least two distinct cyclin-cdk complexes," Molecular and Cellular Biology, vol. 18, no. 2, pp. 753-761, 1998.

[78] Y. Geng, E. N. Eaton, M. Picón et al., "Regulation of cyclin E transcription by E2Fs and retinoblastoma protein," Oncogene, vol. 12, no. 6, pp. 1173-1180, 1996.

[79] J. Fan and J. R. Bertino, "Functional roles of E2F in cell cycle regulation," Oncogene, vol. 14, no. 10, pp. 1191-1200, 1997.

[80] J. DeGregori, T. Kowalik, and J. R. Nevins, "Cellular targets for activation by the E2F1 transcription factor include DNA synthesis- and G1/S-regulatory genes," Molecular and Cellular Biology, vol. 15, no. 8, pp. 4215-4224, 1995.

[81] T. F. Kowalik, J. DeGregori, J. K. Schwarz, and J. R. Nevins, "E2F1 overexpression in quiescent fibroblasts leads to induction of cellular DNA synthesis and apoptosis," Journal of Virology, vol. 69, no. 4, pp. 2491-2500, 1995.
[82] B. Ren, H. Cam, Y. Takahashi et al., "E2F integrates cell cycle progression with DNA repair, replication, and G2/M checkpoints," Genes and Development, vol. 16, no. 2, pp. 245256, 2002.

[83] M. K. Harrison, A. M. Adon, and H. I. Saavedra, "The G1 phase Cdks regulate the centrosome cycle and mediate oncogene-dependent centrosome amplification," Cell Division, vol. 6, article 2, 2011.

[84] J. Zhao, B. K. Kennedy, B. D. Lawrence et al., "NPAT links cyclin E-Cdk2 to the regulation of replication-dependent histone gene transcription," Genes and Development, vol. 14, no. 18, pp. 2283-2297, 2000.

[85] M. Okuda, H. F. Horn, P. Tarapore et al., "Nucleophos$\mathrm{min} / \mathrm{B} 23$ is a target of CDK2/cyclin $\mathrm{E}$ in centrosome duplication," Cell, vol. 103, no. 1, pp. 127-140, 2000.

[86] W. Li, S. Kotoshiba, C. Berthet, M. B. Hilton, and P. Kaldis, "Rb/Cdk2/Cdk4 triple mutant mice elicit an alternative mechanism for regulation of the G1/S transition," Proceedings of the National Academy of Sciences of the United States of America, vol. 106, no. 2, pp. 486-491, 2009.

[87] M. Malumbres and M. Barbacid, "Cell cycle, CDKs and cancer: a changing paradigm," Nature Reviews Cancer, vol. 9, no. 3, pp. 153-166, 2009.

[88] D. Santamaría, C. Barrière, A. Cerqueira et al., "Cdk1 is sufficient to drive the mammalian cell cycle," Nature, vol. 448, no. 7155, pp. 811-815, 2007.

[89] I. Kalaszczynska, Y. Geng, T. Iino et al., "Cyclin A is redundant in fibroblasts but essential in hematopoietic and embryonic stem cells," Cell, vol. 138, no. 2, pp. 352-365, 2009.

[90] P. Loyer, D. Glaise, S. Cariou, G. Baffet, L. Meijer, and C. Guguen-Guillouzo, "Expression and activation of cdks (1 and 2) and cyclins in the cell cycle progression during liver regeneration," Journal of Biological Chemistry, vol. 269, no. 4, pp. 2491-2500, 1994.

[91] J. H. Albrecht, J. S. Hoffman, B. T. Kren, and C. J. Steer, "Cyclin and cyclin-dependent kinase 1 mRNA expression in models of regenerating liver and human liver diseases," American Journal of Physiology, vol. 265, no. 5, pp. G857G864, 1993.

[92] N. H. Zschemisch, C. Liedtke, U. Dierssen et al., "Expression of a cyclin E1 isoform in mice is correlated with the quiescent cell cycle status of hepatocytes in vivo," Hepatology, vol. 44, no. 1, pp. 164-173, 2006.

[93] M. Jaumot, J. M. Estanyol, J. Serratosa, N. Agell, and O. Bachs, "Activation of Cdk4 and Cdk2 during rat liver regeneration is associated with intranuclear rearrangements of cyclin-cdk complexes," Hepatology, vol. 29, no. 2, pp. 385395, 1999.

[94] M. J. Pujol, M. Jaime, J. Serratosa, M. Jaumot, N. Agell, and O. Bachs, "Differential association of p21(Cip1) and p27(Cip1) with cyclin E-CDK2 during rat liver regeneration," Journal of Hepatology, vol. 33, no. 2, pp. 266-274, 2000.

[95] D. O. Morgan, "Cyclin-dependent kinases: engines, clocks, and microprocessors," Annual Review of Cell and Developmental Biology, vol. 13, pp. 261-291, 1997.

[96] C. J. Sherr and J. M. Roberts, "Inhibitors of mammalian G1 cyclin-dependent kinases," Genes and Development, vol. 9, no. 10, pp. 1149-1163, 1995.

[97] J. H. Albrecht, A. H. Meyer, and M. Y. Hu, "Regulation of cyclin-dependent kinase inhibitor p21(WAF1/Cip1/Sdi1) gene expression in hepatic regeneration," Hepatology, vol. 25, no. 3, pp. 557-563, 1997.

[98] J. H. Albrecht, R. Y. C. Poon, C. L. Ahonen, B. M. Rieland, C. Deng, and G. S. Crary, "Involvement of p21 and p27 in the 
regulation of CDK activity and cell cycle progression in the regenerating liver," Oncogene, vol. 16, no. 16, pp. 2141-2150, 1998.

[99] J. F. X. Diffley, "Regulation of early events in chromosome replication," Current Biology, vol. 14, no. 18, pp. R778-R786, 2004.

[100] M. Fujita, "Cdt1 revisited: complex and tight regulation during the cell cycle and consequences of deregulation in mammalian cells," Cell Division, vol. 1, article 22, 2006.

[101] L. W. Wheeler, N. H. Lents, and J. J. Baldassare, "Cyclin A-CDK activity during G1 phase impairs MCM chromatin loading and inhibits DNA synthesis in mammalian cells," Cell Cycle, vol. 7, no. 14, pp. 2179-2188, 2008.

[102] M. Lei and B. K. Tye, "Initiating DNA synthesis: from recruiting to activating the MCM complex," Journal of Cell Science, vol. 114, no. 8, pp. 1447-1454, 2001.

[103] Y. Katsuno, A. Suzuki, K. Sugimura et al., "Cyclin A-Cdk1 regulates the origin firing program in mammalian cells," Proceedings of the National Academy of Sciences of the United States of America, vol. 106, no. 9, pp. 3184-3189, 2009.

[104] A. M. Thomson, P. J. Gillespie, and J. J. Blow, "Replication factory activation can be decoupled from the replication timing program by modulating Cdk levels," Journal of Cell Biology, vol. 188, no. 2, pp. 209-221, 2010.

[105] M. Fujita, Y. Ishimi, H. Nakamura, T. Kiyono, and T. Tsurumi, "Nuclear organization of DNA replication initiation proteins in mammalian cells," Journal of Biological Chemistry, vol. 277, no. 12, pp. 10354-10361, 2002.

[106] R. A. Woo and R. Y. Poon, "Cyclin-dependent kinases and S phase control in mammalian cells," Cell Cycle, vol. 2, no. 4, pp. 316-324, 2003.

[107] F. Zindy, E. Lamas, X. Chenivesse et al., "Cyclin A is required in S phase in normal epithelial cells," Biochemical and Biophysical Research Communications, vol. 182, no. 3, pp. 1144-1154, 1992.

[108] J. Rosenblatt, Y. Gu, and D. O. Morgan, "Human cyclindependent kinase 2 is activated during the $S$ and G2 phases of the cell cycle and associates with cyclin A," Proceedings of the National Academy of Sciences of the United States of America, vol. 89, no. 7, pp. 2824-2828, 1992.

[109] M. C. Cardoso, H. Leonhardt, and B. Nadal-Ginard, "Reversal of terminal differentiation and control of DNA replication: cyclin A and cdk2 specifically localize at subnuclear sites of DNA replication,” Cell, vol. 74, no. 6, pp. 979-992, 1993.

[110] A. M. Adon, X. Zeng, M. K. Harrison et al., "Cdk2 and Cdk4 regulate the centrosome cycle and are critical mediators of centrosome amplification in p53-null cells," Molecular and Cellular Biology, vol. 30, no. 3, pp. 694-710, 2010.

[111] M. Dorée and T. Hunt, "From Cdc2 to Cdk1: when did the cell cycle kinase join its cyclin partner?" Journal of Cell Science, vol. 115, no. 12, pp. 2461-2464, 2002.

[112] D. Arion, L. Meijer, L. Brizuela, and D. Beach, "cdc2 is a component of the M phase-specific histone $\mathrm{H} 1$ kinase: evidence for identity with MPF," Cell, vol. 55, no. 2, pp. 371$378,1988$.

[113] J. Gautier, C. Norbury, M. Lohka, P. Nurse, and J. Maller, "Purified maturation-promoting factor contains the product of a Xenopus homolog of the fission yeast cell cycle control gene cdc2+," Cell, vol. 54, no. 3, pp. 433-439, 1988.

[114] G. Draetta and D. Beach, "Activation of cdc2 protein kinase during mitosis in human cells: cell cycle-dependent phosphorylation and subunit rearrangement," Cell, vol. 54, no. 1, pp. 17-26, 1988.
[115] C. Petretti, M. Savoian, E. Montembault, D. M. Glover, C. Prigent, and R. Giet, "The PITSLRE/CDK11p58 protein kinase promotes centrosome maturation and bipolar spindle formation," EMBO Reports, vol. 7, no. 4, pp. 418-424, 2006.

[116] D. Hu, M. Valentine, V. J. Kidd, and J. M. Lahti, "CDK11p58 is required for the maintenance of sister chromatid cohesion," Journal of Cell Science, vol. 120, no. 14, pp. 2424-2434, 2007.

[117] P. Loyer, J. H. Trembley, J. A. Grenet et al., "Characterization of cyclin L1 and L2 interactions with CDK11 and splicing factors: influence of cyclin 1 isoforms on splice site selection," Journal of Biological Chemistry, vol. 283, no. 12, pp. 77217732, 2008.

[118] T. Bashir and M. Pagano, "Cdk1: the dominant sibling of Cdk2," Nature Cell Biology, vol. 7, no. 8, pp. 779-781, 2005.

[119] O. Tetsu and F. McCormick, "Proliferation of cancer cells despite CDK2 inhibition," Cancer Cell, vol. 3, no. 3, pp. 233245, 2003.

[120] C. J. Sherr and J. M. Roberts, "Living with or without cyclins and cyclin-dependent kinases," Genes and Development, vol. 18, no. 22, pp. 2699-2711, 2004.

[121] S. Ortega, I. Prieto, J. Odajima et al., "Cyclin-dependent kinase 2 is essential for meiosis but not for mitotic cell division in mice," Nature Genetics, vol. 35, no. 1, pp. 25-31, 2003.

[122] C. Berthet, E. Aleem, V. Coppola, L. Tessarollo, and P. Kaldis, "Cdk2 knockout mice are viable," Current Biology, vol. 13, no. 20, pp. 1775-1785, 2003.

[123] R. Vandenbosch, L. Borgs, P. Beukelaers et al., "CDK2 is dispensable for adult hippocampal neurogenesis," Cell Cycle, vol. 6, no. 24, pp. 3065-3069, 2007.

[124] C. Berthet, M. C. Rodriguez-Galan, D. L. Hodge et al., "Hematopoiesis and thymic apoptosis are not affected by the loss of Cdk2," Molecular and Cellular Biology, vol. 27, no. 14, pp. 5079-5089, 2007.

[125] H. Hochegger, D. Dejsuphong, E. Sonoda et al., "An essential role for Cdk1 in S phase control is revealed via chemical genetics in vertebrate cells," Journal of Cell Biology, vol. 178, no. 2, pp. 257-268, 2007.

[126] P. Kaldis and E. Aleem, "Cell cycle sibling rivalry: Cdc2 versus Cdk2," Cell Cycle, vol. 4, no. 11, pp. 1491-1494, 2005.

[127] L. Krasinska, E. Besnard, E. Cot et al., "Cdk1 and Cdk2 activity levels determine the efficiency of replication origin firing in Xenopus," EMBO Journal, vol. 27, no. 5, pp. 758$769,2008$.

[128] W. Li, S. Kotoshiba, and P. Kaldis, "Genetic mouse models to investigate cell cycle regulation," Transgenic Research, vol. 18, no. 4, pp. 491-498, 2009.

[129] A. Satyanarayana, M. B. Hilton, and P. Kaldis, "p21 inhibits Cdk1 in the absence of Cdk2 to maintain the G1/S phase DNA damage checkpoint," Molecular Biology of the Cell, vol. 19 , no. 1 , pp. $65-77,2008$.

[130] A. Satyanarayana, C. Berthet, J. Lopez-Molina, V. Coppola, L. Tessarollo, and P. Kaldis, "Genetic substitution of Cdk1 by Cdk2 leads to embryonic lethality and loss of meiotic function of Cdk2," Development, vol. 135, no. 20, pp. 33893400, 2008

[131] E. A. Hanse, C. J. Nelsen, M. M. Goggin et al., "Cdk2 plays a critical role in hepatocyte cell cycle progression and survival in the setting of cyclin D1 expression in vivo," Cell Cycle, vol. 8, no. 17, pp. 2802-2809, 2009.

[132] M. K. Diril, C. K. Ratnacaram, V. C. Padmakumar, T. Du, M. Wasser, and V. Coppola, "Cyclin-dependent kinase 1 (Cdk1) is essential for cell division and suppression of DNA rereplication but not for liver regeneration," Proceedings of the 
National Academy of Sciences of the United States of America, vol. 109, pp. 3826-3831, 2012.

[133] J. Pines and T. Hunter, "The differential localization of human cyclins $\mathrm{A}$ and $\mathrm{B}$ is due to a cytoplasmic retention signal in cyclin B," EMBO Journal, vol. 13, no. 16, pp. 37723781, 1994.

[134] S. D. Santos, R. Wollman, T. Meyer, and J. E. Ferrell Jr., "Spatial positive feedback at the onset of mitosis," Cell, vol. 149, pp. 1500-1513, 2012.

[135] H. Hochegger, S. Takeda, and T. Hunt, "Cyclin-dependent kinases and cell-cycle transitions: does one fit all?" Nature Reviews Molecular Cell Biology, vol. 9, no. 11, pp. 910-916, 2008.

[136] A. Satyanarayana and P. Kaldis, "A dual role of Cdk2 in DNA damage response," Cell Division, vol. 4, article 9, 2009.

[137] B. S. Ding, D. J. Nolan, J. M. Butler et al., "Inductive angiocrine signals from sinusoidal endothelium are required for liver regeneration," Nature, vol. 468, no. 7321, pp. 310$315,2010$.

[138] T. H. Kim, W. M. Mars, D. B. Stolz, B. E. Petersen, and G. K. Michalopoulos, "Extracellular matrix remodeling at the early stages of liver regeneration in the rat," Hepatology, vol. 26, no. 4, pp. 896-904, 1997.

[139] B. Clement, J. A. Grimaud, and J. P. Campion, "Cell types involved in collagen and fibronectin production in normal and fibrotic human liver," Hepatology, vol. 6, no. 2, pp. 225234, 1986.

[140] A. Temme, T. Ott, F. Dombrowski, and K. Willecke, "The extent of synchronous initiation and termination of DNA synthesis in regenerating mouse liver is dependent on connexin32 expressing gap junctions," Journal of Hepatology, vol. 32, no. 4, pp. 627-635, 2000.

[141] A. Loranger, S. Duclos, A. Grenier et al., "Simple epithelium keratins are required for maintenance of hepatocyte integrity," American Journal of Pathology, vol. 151, no. 6, pp. 1673-1683, 1997.

[142] H. T. Roselli, M. Su, K. Washington, D. M. Kerins, D. E. Vaughan, and W. E. Russell, "Liver regeneration is transiently impaired in urokinase-deficient mice," American Journal of Physiology, vol. 275, no. 6, pp. G1472-G1479, 1998.

[143] M. Shimizu, A. Hara, M. Okuno et al., "Mechanism of retarded liver regeneration in plasminogen activatordeficient mice: impaired activation of hepatocyte growth factor after fas-mediated massive hepatic apoptosis," Нераtology, vol. 33, no. 3, pp. 569-576, 2001.

[144] M. L. Liu, W. M. Mars, R. Zarnegar, and G. K. Michalopoulos, "Collagenase pretreatment and the mitogenic effects of hepatocyte growth factor and transforming growth factor- $\alpha$ in adult rat liver," Hepatology, vol. 19, no. 6, pp. 1521-1527, 1994.

[145] R. Issa, X. Zhou, N. Trim et al., "Mutation in collagen-1 that confers resistance to the action of collagenase results in failure of recovery from CCl4-induced liver fibrosis, persistence of activated hepatic stellate cells, and diminished hepatocyte regeneration," The FASEB Journal, vol. 17, no. 1, pp. 47-49, 2003.

[146] K. Lenhard Rudolph, C. Trautwein, S. Kubicka et al., "Differential regulation of extracellular matrix synthesis during liver regeneration after partial hepatectomy in rats," Hepatology, vol. 30, no. 5, pp. 1159-1166, 1999.

[147] F. F. Mohammed, C. J. Pennington, Z. Kassiri et al., "Metalloproteinase inhibitor TIMP-1 affects hepatocyte cell cycle via HGF activation in murine liver regeneration," Hepatology, vol. 41, no. 4, pp. 857-867, 2005.
[148] T. H. Kim, W. M. Mars, D. B. Stolz, and G. K. Michalopoulos, "Expression and activation of pro-MMP-2 and pro-MMP-9 during rat liver regeneration," Hepatology, vol. 31, no. 1, pp. 75-82, 2000.

[149] D. Schuppan, M. Schmid, R. Somasundaram et al., "Collagens in the liver extracellular matrix bind hepatocyte growth factor," Gastroenterology, vol. 114, no. 1, pp. 139-152, 1998.

[150] F. F. Mohammed, D. S. Smookler, S. E. M. Taylor et al., "Abnormal TNF activity in Timp3-/- mice leads to chronic hepatic inflammation and failure of liver regeneration," Nature Genetics, vol. 36, no. 9, pp. 969-977, 2004.

[151] T. Haruyama, I. Ajioka, T. Akaike, and Y. Watanabe, "Regulation and significance of hepatocyte-derived matrix metalloproteinases in liver remodeling," Biochemical and Biophysical Research Communications, vol. 272, no. 3, pp. 681-686, 2000.

[152] N. Mori, H. Sato, T. Hayashibara et al., "Helicobacter pylori induces matrix metalloproteinase- 9 through activation of nuclear factor $\kappa \mathrm{B}$," Gastroenterology, vol. 124, no. 4, pp. 983992, 2003.

[153] T. Knittel, M. Mehde, D. Kobold, B. Saile, C. Dinter, and G. Ramadori, "Expression patterns of matrix metalloproteinases and their inhibitors in parenchymal and nonparenchymal cells of rat liver: regulation by TNF- $\alpha$ and TGFß1," Journal of Hepatology, vol. 30, no. 1, pp. 48-60, 1999.

[154] L. K. Hansen and J. H. Albrecht, "Regulation of the hepatocyte cell cycle by type I collagen matrix: role of cyclin D1," Journal of Cell Science, vol. 112, no. 17, pp. 2971-2981, 1999.

[155] K. De Smet, P. Loyer, D. Gilot, A. Vercruysse, V. Rogiers, and C. Guguen-Guillouzo, "Effects of epidermal growth factor on CYP inducibility by xenobiotics, DNA replication, and caspase activations in collagen I gel sandwich cultures of rat hepatocytes," Biochemical Pharmacology, vol. 61, no. 10, pp. 1293-1303, 2001.

[156] M. Nagaki, A. Sugiyama, T. Naiki, Y. Ohsawa, and H. Moriwaki, "Control of cyclins, cyclin-dependent kinase inhibitors, p21 and p27, and cell cycle progression in rat hepatocytes by extracellular matrix," Journal of Hepatology, vol. 32, no. 3, pp. 488-496, 2000.

[157] G. Baffet, P. Loyer, D. Glaise, A. Corlu, P. L. Etienne, and C. Guguen-Guillouzo, "Distinct effects of cell-cell communication and corticosteroids on the synthesis and distribution of cytokeratins in cultured rat hepatocytes," Journal of Cell Science, vol. 99, no. 3, pp. 609-615, 1991.

[158] E. W. Olle, X. Ren, S. D. McClintock et al., "Matrix metalloproteinase-9 is an important factor in hepatic regeneration after partial hepatectomy in mice," Hepatology, vol. 44, no. 3, pp. 540-549, 2006.

[159] G. M. Argast, J. S. Campbell, J. T. Brooling, and N. Fausto, "Epidermal growth factor receptor transactivation mediates tumor necrosis factor-induced hepatocyte replication," Journal of Biological Chemistry, vol. 279, no. 33, pp. 34530-34536, 2004.

[160] V. Gkretsi, U. Apte, W. M. Mars et al., "Liver-specific ablation of integrin-linked kinase in mice results in abnormal histology, enhanced cell proliferation, and hepatomegaly," Hepatology, vol. 48, no. 6, pp. 1932-1941, 2008. 


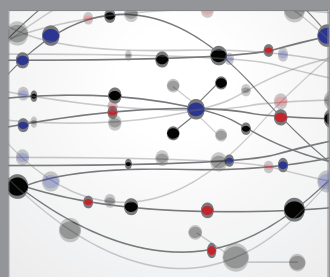

The Scientific World Journal
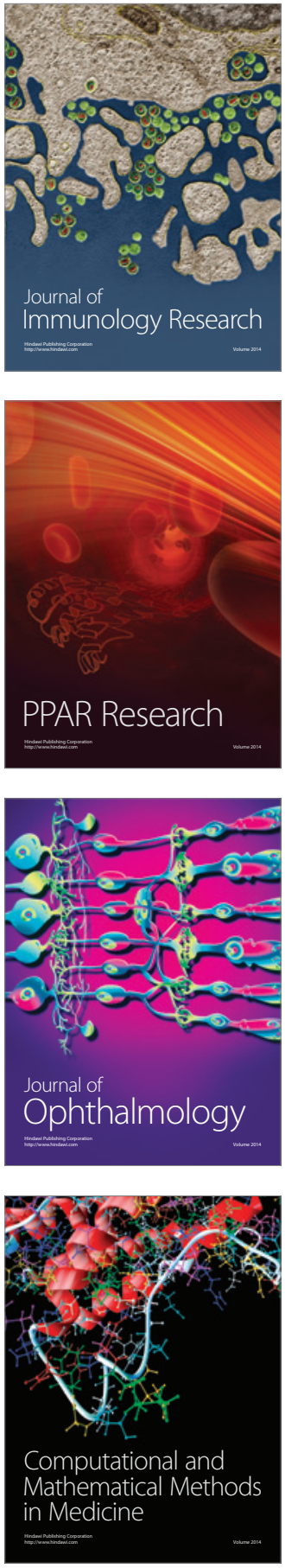

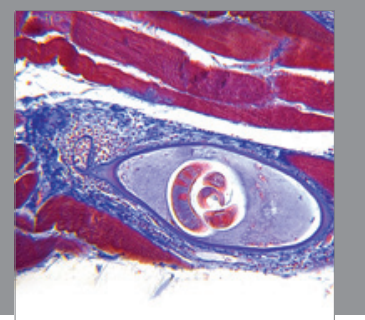

Gastroenterology

Research and Practice
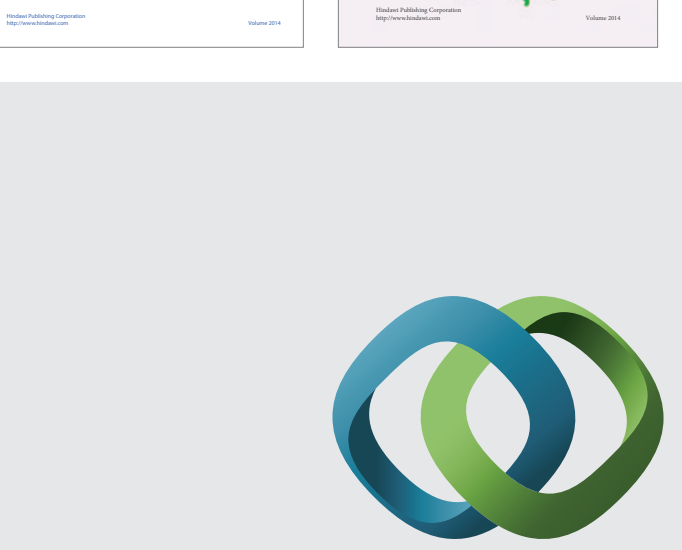

\section{Hindawi}

Submit your manuscripts at

http://www.hindawi.com
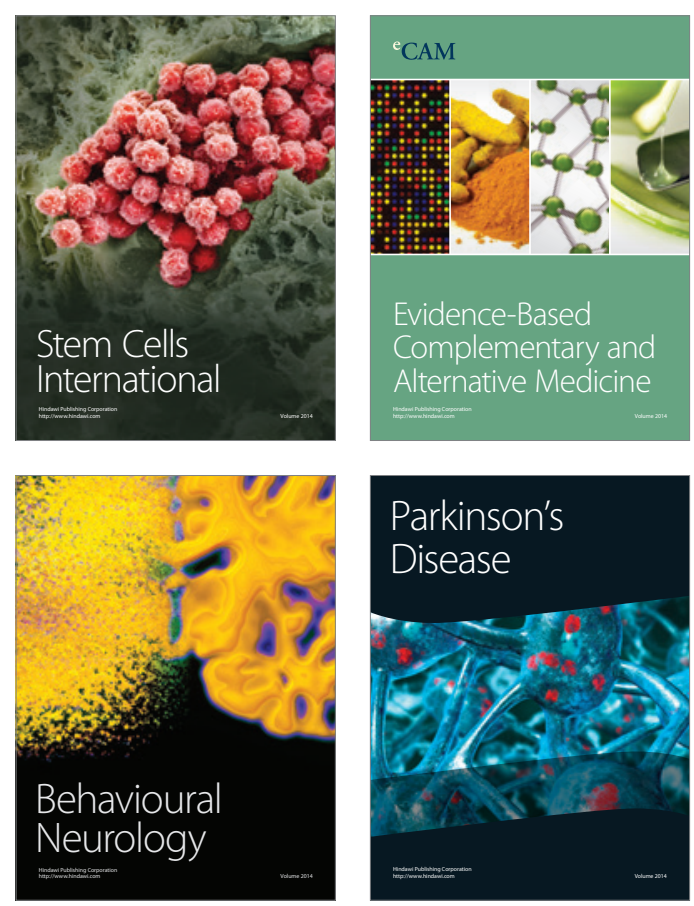

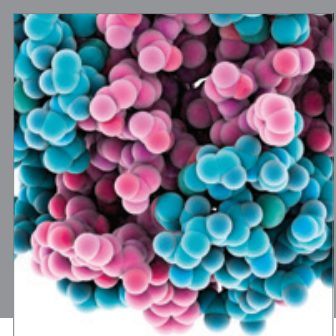

Journal of
Diabetes Research

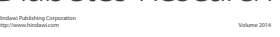

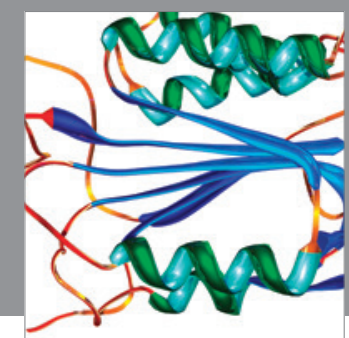

Disease Markers
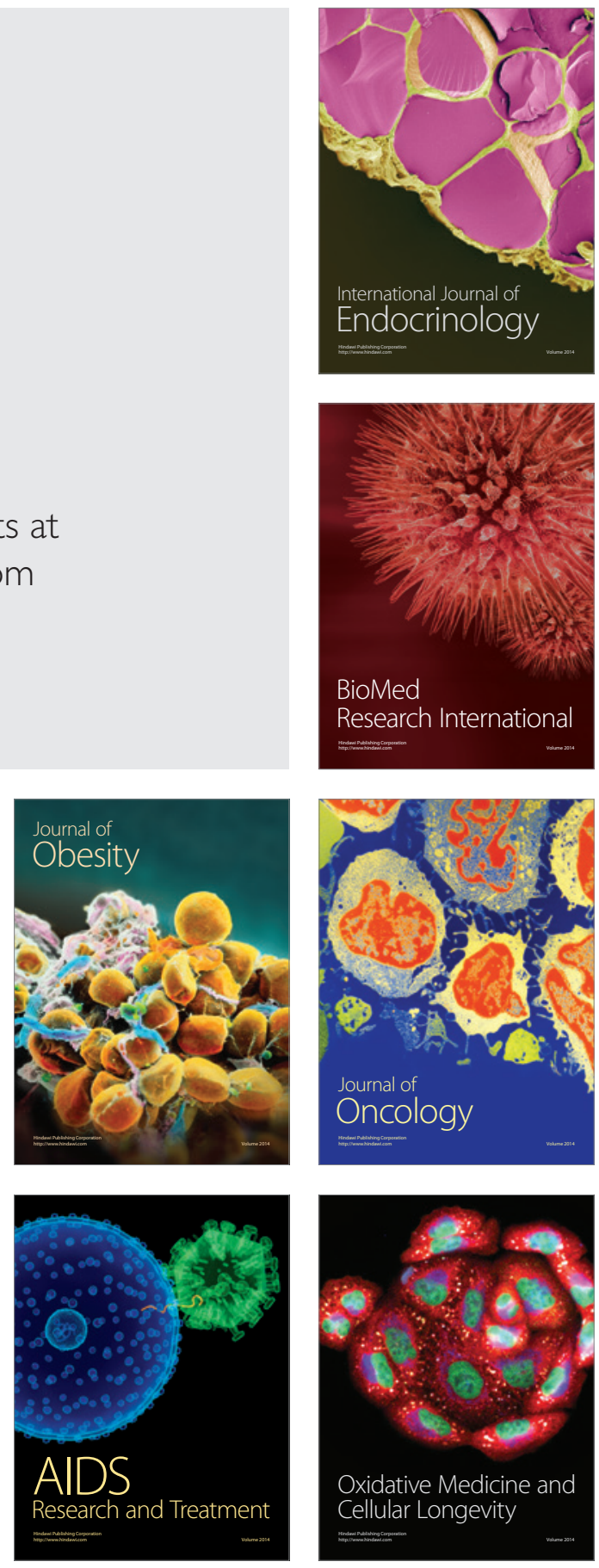